\title{
ĒDOLES BAZNĪCAS IEKĀRTA: KOKTËLNIEKA TOBIASA HEINCA 1647./1648. GADĀ DARINĀTĀ ALTĀRA UN KANCELES TEOLOĢISKIE VĒSTİJUMI
}

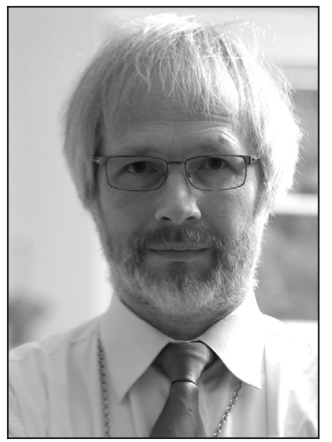

Ralfs Kokins ir teolog̣ijas zinātnu doktors, LU Teolog̣ijas fakultātes profesors, vadošais pētnieks, kā arī Latvijas Evaņgēeliski luteriskās baznīcas mācītājs. Doktora zinātnisko grādu ieguvis Heidelbergas Universitātes (Ruprecht-Karls-Universität Heidelberg) Teologijas fakultātē (Jaunās Derības teolog̣ija un analītiskā filozofija). Zinātniski pētnieciskā un akadēmiskā darba jomas: Jaunās Derības tekstu ekseǵēze un teolog̣ija, Nag-Hammadi koptu papirusu tulkošana un pētniecība, pirmkristīgais laikmets un literatūra, seno tekstu zinātniskās pētniecības metodika, vēsturiskais Jēzus, protestantiskā teolog̣ija, sakrālā arhitektūra, māksla un teoloǵija, folkloristiski leǵendāro materiālu pētniecība. Vairāku grāmatu un daudzu zinātnisko publikāciju autors Latvijā un ārzemēs.

Raksturvārdi: Ēdoles baznīca, Tobiasa Heinca kokgriezumi, Baznīcas māksla un teologíja.

Latvijas ainava bez tās senajiem, skaistajiem dievnamiem nav iedomājama. Jau 370 gadus Ëdoles (senais nosaukums: Edvalia, vēlāk - Edwahlen) centrā (Alsungas, Kuldīgas un Zlēku ceḷa krustojumā), vēsturiskā akmens žoga ieskauta, majestātiski stāv baznīca, kas kopā ar vareno viduslaiku pili un ezeru nosaka šīs vietas tik glezno un neatkārtojamo ainavisko raksturu (1. attēls) ${ }^{1}$. Ėdoles baznīcas celtniecība, dievnama un draudzes vēsture ${ }^{2}$

1 Ēdoles ainavu (kurā redzama baznīca, pils, ezers ar salu un torni, dzirnavas un atseviškas ēkas) 1795. gadā zīmējis arī Johans Kristofs Broce (Brotze 1997). J. K. Broce gan nav zìmējis Ëdoles baznīcas interjera elementus.

2 Pirmo plašāko vēsturiski vērtīgo pētījumu par Ēdoles baznīcas un draudzes vēsturi veicis A. Ozolinšs (Ozolinšs 1937). Tajā minētie vēstures fakti, balstiti uz dokumentiem un draudzes saistās ar paz̄stamajām Kurzemes hercogistes baronu fon Bēru ${ }^{3}$ un fon Maidelu dinastijām. Kopā ar Landzes baznīcu (celta pēc Kurzemes hercoga Gotharda Ketlera 1567. gada edikta, minēta kā pabeigta jau 1609. gadā), Zlēku baznīcu (celta 1647. gadā) un Ugāles baznīcu (celta 17. gs. beigās) Ēdoles baznīca lieliski iekḷaujas tās puses unikālāko, savdabīgāko un skaistāko baznīcu lokā.

Uz Ėdoles draudzi tiku savulaik arhibīskapa Kārḷa Gailīša nosūtìts pildīt mācītāja pienākumus kā stud. theol. (1991-1994), tajā laikā savācu daudz nostāstu un liecību gan no vecajiem draudžu locekḷiem, gan arī fon Bēru dinastijas pārstāvjiem, kuri tajā laikā baznīcu bieži apciemoja un palīdzēja tās

arhīviem, kas nav saglabājušies līdz mūsdienām, ir pamatā vairumam mūsdienu aprakstu.

3 Ēdoles baznīcas vēstures fragmenti ir publicēti pašas fon Bēru dinastijas skatījumā (Behr 1979), lai gan tieši baznīcas celtnei un tās interjera datējumam, autorībai u. c. jautājumiem šajā grāmatā netiek pievērsta liela uzmanība. 


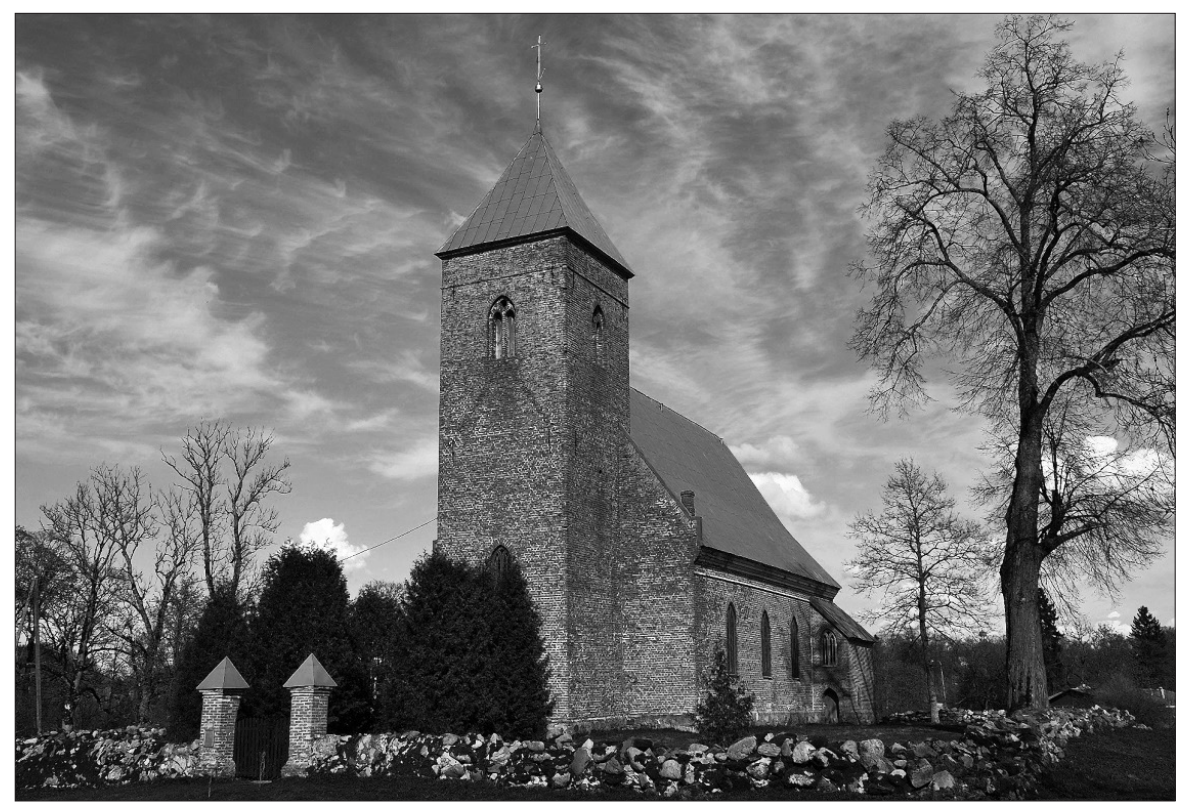

1. attēls. Ėdoles baznīca. Foto: Ralfs Kokins, 2015

izpētē. Lielākoties gan tā bija tikai mutiska, no paaudzes paaudzē nodota informācija, jo vairums dokumentu un seno arhīva materiālu ir neatgriezeniski zuduši.

Līdz 1992. gada rudens vētrām baznīcu ieskāva milzịgi simtgadīgi koki (liepas vairāk nekā $4 \mathrm{~m}$ diametrā). Līdz ar pēdējo gadu desmitu klimatiskajām pārmaiṇām arvien biežākas kḷuva postošas vētras, krītošie koki un to zari jau regulāri bojāja seno baznīcu (tās jumtu, fasādi, logus).

Koku izpētē atklājās to bēdīgais stāvoklis (gandrīz visi bija ar iztrunējušu vidu un miršanas stadijā), līdz ar to tika pieņemts grūts un vēl ilgi diskutêts lēmums tos nozāgeèt, lai saglābtu pašu baznīcu.

Baznīcas celtne ir masīva, vienjoma, sarkanu ķieǵeḷu gareniski veidota mūra celtne ar tradicionālu novietojumu (tornis pret rietumiem/dienvidrietumiem, altārdaḷa pret austrumiem/ziemeḷaustrumiem). Baznīcai ir laukakmeņu mūra pamati, zem baznīcas grīdas plašas kapenes.

Draudzes telpai (ar 250 sēdvietu) ir proporcionāli l, loti augsts un stāvs jumts, kura tehniskais risinājums ir pieminēšanas vērts. Kvadrātiskais tornis organiski piekḷaujas celtnei, to rotā piramidāla jumta smaile ar augstu novietotu lodi, gaili un krustu galā. Mūrējumā skaidri saskatāms, ka tornis būvēts (paaugstināts) vairākos posmos. Līdz pat 20. gs. sākumam virs ieejas esot bijis arī īpatnējas formas koka jumtiņš, bet tas vairs nav atjaunots. Sākotnēji arī torņa smaile bija izliektāka un smailāka, kā tas bija raksturīgs viduslaiku baznīcas arhitektūrā (līdzīgi kā netālu esošajai Landzes baznīcai), bet vēlāko gadsimtu pārbūvēs tika vienkāršota piramidālā formā. Kopš 20. gs. 20. gadiem (1928?) baznīcai un tornim uzlikts skārda jumts. Torņa augšdaḷā izteiksmīgi gotiski logi uz visām četrām debespusēm, bet pati ieeja baznīcā ir ar profilētu ķieǵeḷu mūrējumu, lai virzienā uz durvīm veidotos izteikta dzilumperspektīva.

Celtnes altārdaḷa būvēta poligonāla, tai piekḷaujas arī sakristeja. Baznīcas celtnes dienvidu dậā ir vēl kāda interesanta piebūve draudzes telpai - atsevišķa ieeja (ar gotisku gala logu un izliektām trepēm) Kungu ložā (iepretī altārim).

Baznīca ir izcils piemērs, kā viduslaiku veidolā tik meistarīgi tiek apvienoti gan agrākās gotikas, gan arī pēcgotikas (vācu - Nachgothik) un manierisma elementi.

Saskan̄ā ar tolaik vēl dzīvajām viduslaiku teoloğiskajām tautas tradīcijām baznīca celta barona un Ėdoles pils īpašnieka Johana Dītriha fon Bēra (Johann Dietrich von Behr) 
laikā - 1647./1648. gadā par viņa sievas Sibillas fon Bēras (Sibylla von Behr) līdzekḷiem kā Grēku izpirkšanas baznīca (Sühnekirche).

Baznīcu tik īpašu dara viena no Kurzemes muižniecības romantiskākajām vēsturiskajām leǵendām, kas saistīta ar tās celtniecību. Leǵendas dažādo un vēsturiski tik pretrunīgo variantu pamatā ir stāstījums par brāļa slepkavību mīlestības dēl - Johans Dītrihs fon Bērs un viņa brālis Filips Sigismunds fon Bērs (Philipp Sigismund von Behr) iemīl Cīravas muižas īpašnieka Hermaņa fon Maidela (Hermann von Maydell) izslavēti skaisto meitu Sibillu fon Maidelu (Sibylla von Maydell), un kāda asa strīda laikā Johans Dītrihs pils otrā stāva zālē esot nodūris savu brāli Filipu Sigismundu, vēlāk šì baisā grēka izpirkšanai viņš cēlis Ēdoles baznīcu ${ }^{4}$.

Vēsturiskā patiesība, kas izriet no daudzajiem fon Bēru dinastijas vēstures materiāliem un ǵenealoǵijām, ir cita - 1623. gada 26. jūlijā Filips Sigismunds fon Bērs (Philipp Sigismund von Behr) ar kāda kalpa palīdzību nogalina savu tēvu Verneru fon Bēru (Werner von Behr $)^{5}$, pats pēc tam aizbēg uz Poliju, lai izvairītos no soda, bet šīs slepkavības patiesie iemesli no fragmentārajiem vēstures avotiem paliek neskaidri.

Vēlākos laikos uz zāles sienas esot bijis redzams tumšs (asinu??) plekiis, kuram priekšā 19. gs. uzbūvēts kamīns. Šis nostāsts vēl pašlaik ir dzīvs Ēdoles puses l̦aužu stāstījumos, tāpat kā nostāsti par paranormālām parādībām Ėdoles pils telpās, kā arī netālu esošajā doktorāta êkā (baltā vai zaļganā tērpta dāma pilī un "lienošs ǵindenis" doktorātā).

Baznīcas "grēku izpirkšanas" raksturu izcel kāds savāds apbedījums pie baznīcas durvju sliekšña. Fon Bēru dzimtas dokumentos minēts, ka grēku izpirkšanas (Sühne) nolūkos zem baznīcas sliekšña akmens esot apglabāts Ulrihs fon Bērs (Ulrich von Behr, miris 1677. gadā), sekojot viṇa testamentā izteiktajai gribai, bet tautas nostāstos tur apbedìtā persona ir leǵendārais Johans Dītrihs fon Bērs ${ }^{6}$.

4 Mašnovskis 2005, 346.

5 Šì versija pārstāvēta: Ķiploks 1987, 406; Rusmanis, Vīks 1993, 63.

6 Rusmanis, Vīks 1993, 63-64. Johans Dītrihs (kurš tautas nostāstos tiek identificēts kā
Tomēr apbedījuma izpēte atklāj arī vēsturisko avotu nepilnības vai mums pieejamās informācijas trūkumus. 1910. gadā notikusi šī savādā un nostāstiem apvītā apbedījuma atvēršana un izpēte, kurā tika noskaidrots, ka tur ir apglabāts nevis ǵenealoǵijās minētais Ulrihs fon Bērs un leǵendās izceltais Johans Dītrihs fon Bērs, bet gan pulkvežleitnants, Ulriha fon Bēra 1722. gadā mirušais mazdēls Ulrihs fon Bērs ${ }^{7}$. Varbūt sākotnēji zem sliekšņa bijis paglabāts vecais Ulrihs vai pat Johans un pēc kāda laika (kad nākusi kāda neikdienišķa zīme no debesīm, ka grēki piedoti) ${ }^{8}$ saskaņā ar viduslaikos zināmu praksi notikusi pārapbedīšana ierastajā vietā (dzimtas kapenēs), un varbūt tā bijusi no viduslaikiem mantota dzimtas reliǵiska tradīcija. L,oti iespējams, ka arī 18. gs. dzīvojošais Ulrihs fon Bērs savu grēku izpirkumam licis apglabāt sevi zem baznīcas sliekšña (kuru deldē baznīcēnu kājas), tāpat kā viṇa priekšteči.

Vēsturiskie fon Bēru dzimtas materiāli ir lıti fragmentāri (daudzi dokumenti gājuši zudīiā), tajos vērojamas hronologiskas, vārdu atveides u. c. pretrunas, kā arī dažādi faktologiski trūkumi.

Līdz galam vēsturisko patiesību vairs nav iespējams noskaidrot, jo uz Vāczemi aizvestie fon Bēru dokumenti lielākoties gājuši bojā Otrā pasaules kara laika Vācijas pilsētu bombardēšanās, arī pašas draudzes vēsturiskie regiistri pazuduši bandītiskajos padomju okupācijas gados. Tāpat arī trimdas latviešiem (baznīcas vēsturniekam Edgaram Kiplokam u. c.) informācija par Ēdoles baznīcas vēsturi bija pārsteidzoši trūcīga. Pētīta un aprakstīta šì baznīca ir neizprotami maz un nepilnīgi.

Tieši Ēdoles baznīcas sakristejā (mācītāja gèerbkambarī) Krišjānis Valdemārs 1848. gadā

slepkava) licis sevi apbedīit zem baznīcas sliekšṇa saskanāa ar viduslaiku ticējumu, ka grēki tiks piedoti, kad baznīcēnu kājas akmeni būs nodeldējušas.

7 Mašnovskis 2005, 351.

8 Vēl mūsdienās tiek stāstīts nostāsts, ka attiecīgā "zīme no debesīm" bijis zibens spēriens, kurš kapakmeni pāršķēlis pušu. Senā apbedījuma plāksne pie ieejas durvīm patiešām ir pārplīsusi, bet nav pētìts, kā plaisa radusies. 


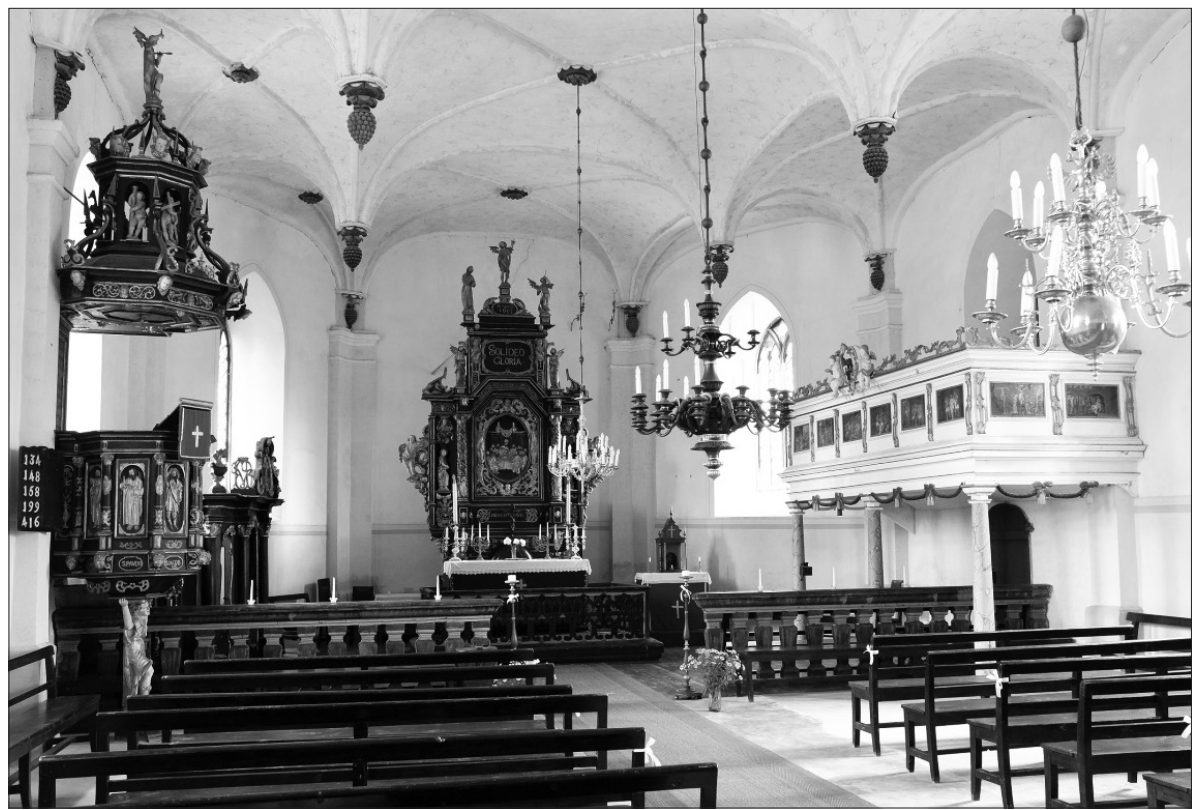

2. attēls. Ēdoles baznīcas interjers. Foto: Ralfs Kokins, 2018

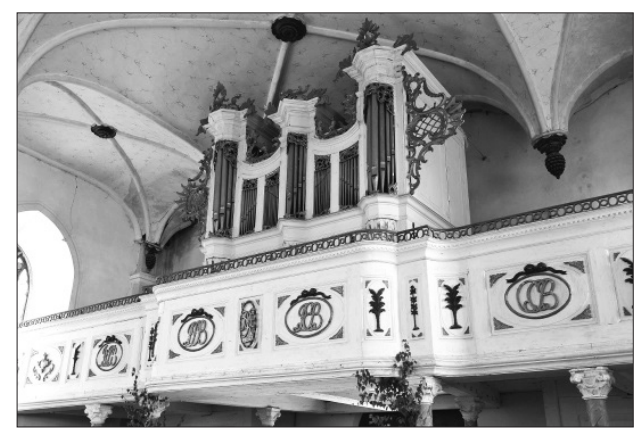

3. attēls. Ērǵgel̦u lukta un ērğeḷu prospekts. Foto: Ralfs Kokins, 2018

ar toreizējā draudzes mācītāja K. G. Šmita atbalstu ierīkoja pirmo latviešu bibliotēku? .

Baznīcas manierisma un rokoko iekārta ${ }^{10}$ (2. un 3. attēls) ir patiesi pārsteidzoša, tā ir viena no vissavdabīgākajām un greznākajām

9 Rusmanis, Vīks 1993, 64. Pirms pāris gadiem pie sakristejas ir piestiprināta attiecīga memoriāla plāksne.

${ }^{10}$ Izcils baroka laikmeta, manierisma un rokoko stila raksturojums (fonā esošās idejas, kultūra, māksla, dzīvesstils u. c.): Grīns 1931, 7-13, 86-97 (baroka laikmets un rokoko gadu simtenis), 162-164 (rokoko laikmeta stils un gars). visā Kurzemēe $\bar{e}^{11}$, tā ir dažādu meistaru ${ }^{12}$ darināta no apmēram 1647./1648. gada līdz pat 18. gs. otrajai pusei.

Baltais un krāšñi zeltītais rokoko stila ērǵeḷu prospekts (3. attēls) veidots no vairākām

11 Erudīti plašu, kontekstuālu un pat mūsdienās izmantojamu pētījumu par baroka laika mākslu (tēlniecību) Latvijā (Kurzemes hercogistē) skat. Vipers 1937, 161ff (tēlniecība); vispārēja

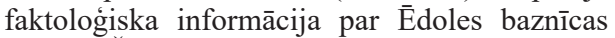
iekārtu: Švābe et al. 1929-1930.

12 Kiploks 1987, 406 atrodama neprecīza informācija, ka "baznīca izdaiļota ar Sefrena u. c. kokgriezumiem". Ēdoles baznīcas iekārta nav Nikolausa Sēfrensa darinājums. 


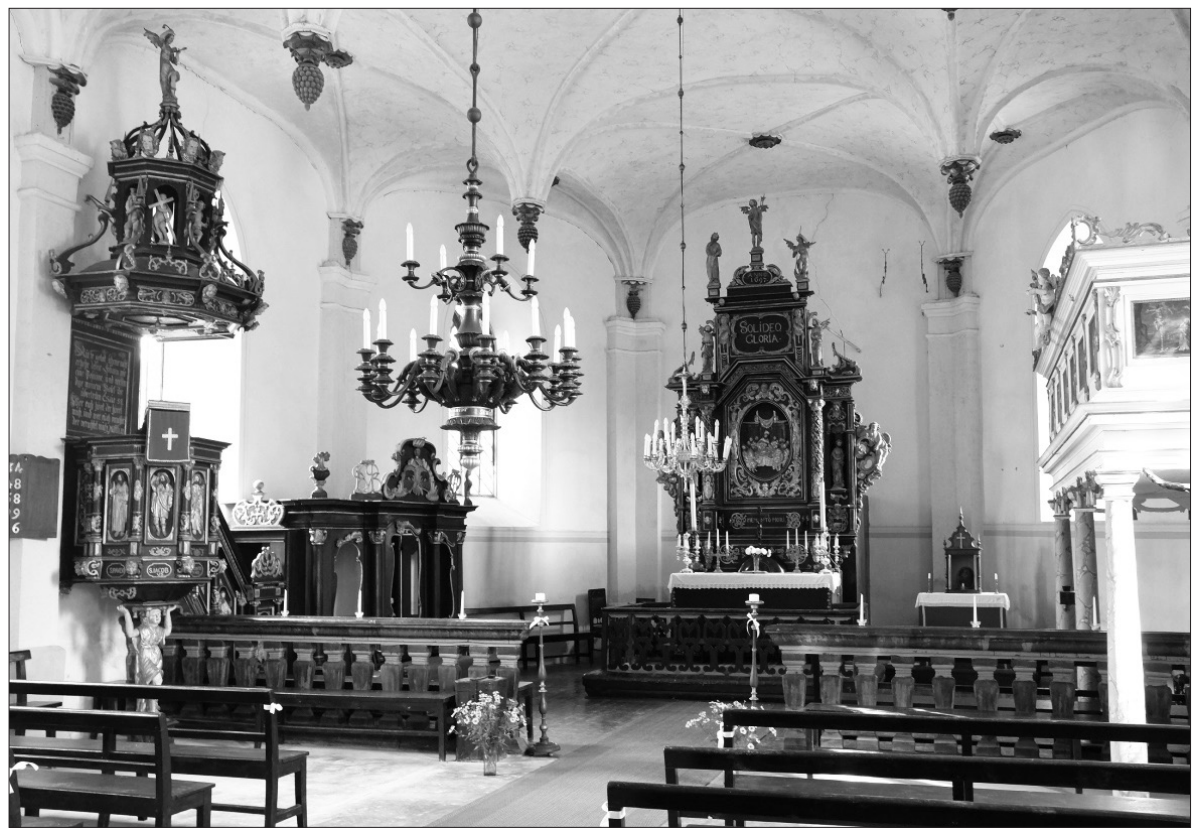

4. attēls. Ēdoles baznīcas interjers. Foto: Ralfs Kokins, 2018

stabul̦u grupām, ko apvij zeltīti rokaju ornamenti, bet prospekta sānu spārnus papildina dāsni un gaisīgi rotājumi (treljāža). Ērǵeḷu lukta ir ne mazāk grezna, tā balstās uz sešām korintiskā ordera kolonnām (ar marmoru imitējošu krāsojumu, uz augstiem cokoliem). Luktas augšējā mala greznota ar zeltîtu rotājumu, bet tās priekšpuses septiņos pildņos redzami reljefi rokaji, fon Bēru dzimtas monogrammas, kā arī vēl neatšifrēta monogramma $M . M$. K. ar gadskaitli 1784 .

Ēróeles 1786. gadā Tukumā uzbūvējis prūšu meistars Kristofs Vilhelms Bravelaits, tās 1840. un 1852. gadā salabo un nedaudz pārbūvē paz̄istamais ērǵel̦meistars Kārlis Hermanis no Liepājas, bet nākamā pārbūve notiek 1902. gadā (to veic vinga dēls Aleksandrs Hermanis) $^{13}$.

Ërǵeḷu prospekts un lukta ir pieskaņoti rokoko stilā veidotajai Kungu ložai (2. attēlā pa labi), kas pamatā būvēta 17. gs. beigās. Sākotnēji tā bijusi vienkārša, ar krāsainiem gleznojumiem (Kristus ciešanu stāsta ainas), bet rokoko laikā tā papildināta ${ }^{14}$ ar grezni zeltīitiem

\footnotetext{
13 Mašnovskis 2005, 350.

14 Turpat, 347.
}

rotājumiem, festoniem ar piekariem, rokajiem un fon Bēru gerboni (to tur divi enğgelii).

No inženiertehniskā viedokḷa apbrīnas vērti ir baznīcas greznie, tehniski tik sarežgîiti veidotie griesti, kas rada gluži neticamu viegluma iespaidu (2. un 3. attēls). Ar ǵipsi apmestos un marmora gleznojumu pārklātos koka griestus veido trīsjomu stalaktītu velves, kas sadalītas 15 travejās, imitējot viduslaiku vēlās gotikas stilā celto katedrāḷ griestu konstrukcijas. Velvju apakšējās savienojuma vietās - gaumīgi piekari vīnogu ķekaru vai čiekuru formā, bet cokolos greznas rozetes. Pārsteidzošs ir fakts, ka stalaktītu velves nav ierasti atbalstītas ar kolonnām, līdz ar to griesti pa vidu nekur nebalstās, bet ar ārkārtīgi sarežḡîtu koka konstrukciju baznīcas bēniņos nospriego paši sevi (pēc gandrīz 400 gadiem griesti vēl ir taisni un nav vidū ieliekušies vai kā citādi deformējušies!).

Baznīcā ir trīs iespaidīgi kronlukturi, vecākais (no Teplicas) ir datējams ar 19. gs. vidu.

Altārtelpu no draudzes telpas nodala masīva koka letners (sēta), tās priekšā novietots baznīcas vecākais priekšmets - senā naudas lāde (melns koks, dzelzs apkalumi ar atslēgu) vēl no agrākās, 14. gs. celtās koka baznīcas 
(redzams 4. attēlā aiz ziedu vāzes) ${ }^{15}$. Gan draudzes, gan altārtelpas sienas atbilstoši griestu travejām sadala ieliekti pilastri, gotiskās logailas pildītas ar sīkām rūtīm, kas kḷūst rakstainas un krāsainas smailloka arku augšdaḷā.

Manierisma un rokoko stila saspēle šajā baznīcā ir patiesi fenomenāla. Gaumīgais un arhetipiski tik iedarbīgais baznīcas interjers ${ }^{16}$ atstāj uz cilvēku spēcīgu emocionālu iespaidu, telpa nojauc laika robežas, likdama apmeklētājam "izkāpt" no sava steidzīgā laika un ieiet citā laika plūdumā, šksietami citā gadsimtā, citā lietu kārtībā. Baznīcā pat dienas laikā valda pieklusināta gaisma, ir patumšs. Neskatoties uz to, puskrēsla un melnais interjers nav nospiedošs, tieši pretēji - viss izskatās kā spožā gaismā, arī gaiss ir tīrs un sauss, nav senajos dievnamos tik izplatītās mitruma un pelējuma smakas. Kokgriezumu un rotājumu silueti rada gaismas staru nobīdes un laušanas ilūziju, gluži kā priekšmetus aplūkojot spožā saules pretgaismā (ar izplūdušām, robainām kontūrām). Šis viegluma un sapņainās gaismas efekts šajā dievnamā ir kas patiesi negaidīts un fenomenāls.

Atsevišks pētījums būtu veltāms Ēdoles baznīcas kādreizējiem zvaniem. Vecākais, $115 \mathrm{~kg}$ smagais, masīvi lietais zvans datējams aptuveni ar baznīcas celšanas laiku (17. gs. beigas), uz tā mīklains, līdz šim vēl neatšifrēts uzraksts $O+$ Christe + Jesu + bidde + got + vor + hinrick + enderling de $+i m+$ goth $^{17}$. Nevienā aprakstā vai pētījumā neesmu redzējis šĩ teksta atšifrējumu vai skaidrojumu, daḷa vārdu neko nenozīmē. Esmu meklējis atbildes pie Heidelbergas Universitātes (Vācijā) Baznīcas vēstures un viduslaiku vācu valodas pētniekiem - iespējams, ka teksts ir fragments vai nu no kādas senas, tautā populāras Zvana dziesmas (viduslaikos tautā tik izplatītais skaitāmpantiņu žanrs), vai arī kādas jau zudušas baznīcas dziesmas rindu vai pantu elementu

${ }^{15}$ Agrākā koka baznīca (pils kapella?) 16. gs. sākumā bijusi jau sagāzusies. Ķiploks 1987, 406.

16 Vispārīgu pētījumu par to laiku koktēlniecības darbnīcām un to îpatnībām skat. Grosmane 2001.

17 Campe 1930, 172 (noraksts: Theodor Funk). Par citiem Ēdoles baznīcas zvaniem skat. turpat 6, 12, 131, 164-169. Neprecīzi uzraksts atainots Mašnovskis 2005. virknējums. Vietējos nostāstos ir pat versija par kādu teiksmainu "rūḳī̌su valodu" (klīst arī dažādi nostāsti par rūkīšsu līgumu ar fon Bēriem pils sakarā, par Rūḳišsu ozolu, kurš jāsaglabā, lai pils nenogrimtu dzelmē, utt.).

Baznīcas torn̄̄ bijuši vēl vairāki zvani 1740. gadā Jelgavā (Mitau) lietais zvans ar uzrakstu 1740. Vivos voco, mortuos plango, fulgara frango (kuru pārlej Popē 1852. gadā), pirms 1823. gada liets zvans ${ }^{18}$ (bez datējuma; tas saplīst un tiek no jauna pārliets 1841. gadā ar garākiem tekstiem), savukārt pašreiz baznīcas torn̄̄ dievkalpojumus iezvana 1939. gadā (Liepājas drāšu fabrikā) lietais zvans ${ }^{19}$.

Tāpat atsevišķa pētījuma vērti būtu zudušie fon Bēru dzimtas karogi, ǵerbon,i, epitāfijas un pat bruņinieku bruņas, kas vēl 20. gs. pirmajā pusē bijušas eksponētas pie baznīcas sienām (vēl tagad altārtelpā pie tām redzami grezni āḳi), bet 1920. gada degradējošās agrārreformas un Otrā pasaules kara laikā neatgriezeniski zudušas ${ }^{20}$, arī pēc pašu fon Bēru liecībām liels skaits vērtību zudušas Otrajā pasaules karā.

Tomēr paši vecākie, vērtīgākie un savdabīgākie baznīcas iekārtas elementi ir melni krāsotais un zeltītais altāris un kancele, kuru ap 1647./1648. gadu Johans Dïtrihs fon Bērs ir pasūtinājis koktēlniekam Tobiasam Heincam (Tobias Heinz, 1589-1647?). Altāris un kancele veidoti krāšņā un savdabīgā ziemeḷu renesanses jeb manierisma stilā, kāds raksturīgs tikai tālaika Kurzemei. Ēdoles baznīcas altāris un kancele ir îpaši arī ar to, ka tie ir paši pēdējie š̄ meistara darinājumi ${ }^{21}$.

18 Uz šī zvana uzraksts Soli Deo Gloria x Adolfine Eveline von Behr $x$ Wenn du hörst mein helles Klingen, sollst du Gott ein Opfer bringen $x$ Lobe den Herrn, meine Seele $x$ Und vergiss nicht, was er dir Gutes getan hat.

19 Atsaucoties uz iepriekš minēto arhitektūras vēsturnieka P. Kampes pētījumu: Mašnovskis 2005, 351.

20 Par zudušajiem Ēdoles baznīcas priekšmetiem skat. Spārītis 1995.

21 Avotos ir nesakritības - kā Tobiasa Heinca nāves gads visur minēts 1647., bet Johanna D. von Bēra pasūtījums meistaram datēts tikai ar 1648. gadu. Varbūt pasūtījums pieņemts jau agrāk, tikai maksājums iegrāmatots 1648. gadā un darbu pēc meistara nāves pabeidza vina 


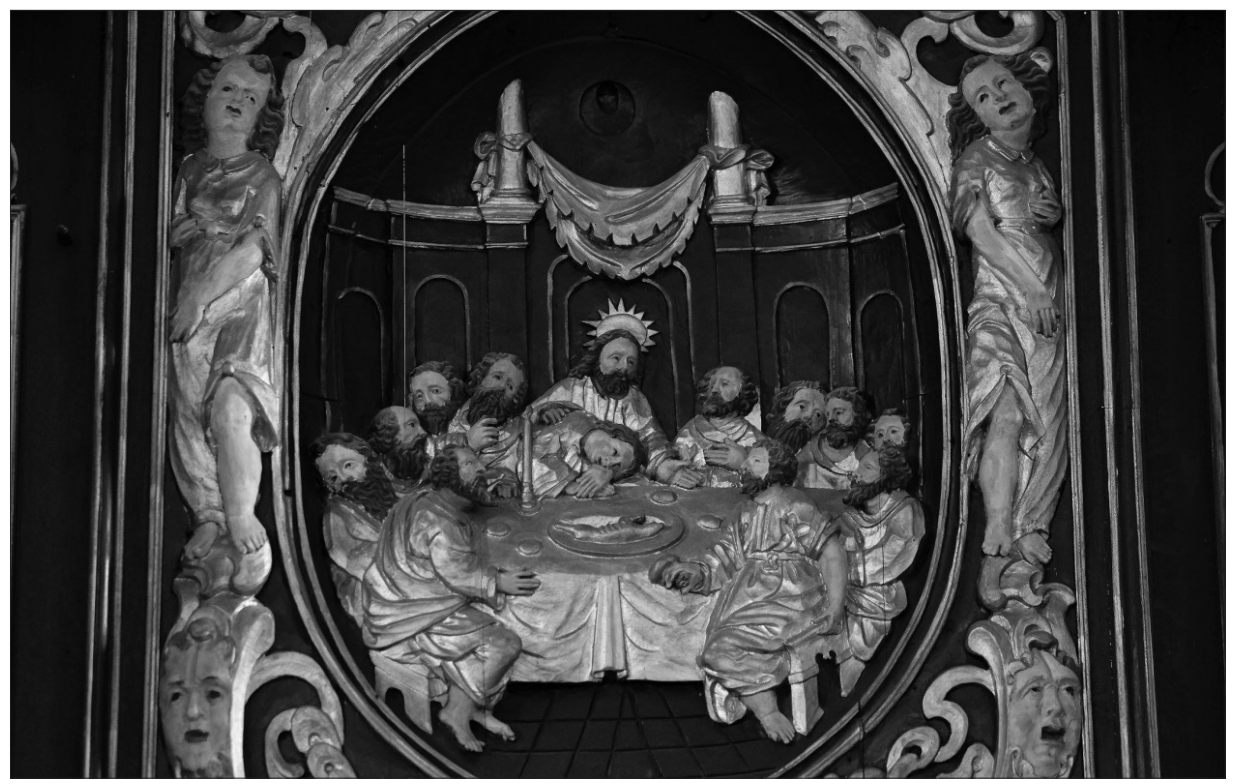

5. attēls. Ėdoles baznīcas altāra cilnis Svētais Vakarēediens. Foto: Ralfs Kokins, 2018

Baznīcas krāšņais, gaumīgais, proporcijās teju ideālais altāris ir ḷoti īpatnēji un arhetipiski iespaidīgi veidots, tā kompozīcijā nolasāms spēcīgs vairāku līmeņu teoloǵisks vēstījums. Retabla pamatā (predellā) zeltītā kartušā horizontāli izkārtots iespaidīgs uzraksts $M E M E N$ TO MORI (altārī kalpojošā mācītāja acu augstumā!), tā sānos lakoniskas arabeskas. Altāra retabla centrālajā dạ̦ā, ovālā medaljonā grezni veidots cilnis, kurā atainots Svētais Vakarēdiens (Jēzus pēdējais Passā mielasts Jeruzalemē kopā ar saviem 12 mācekḷiem). Pārsteidz šì manierisma labākajās tradīcijās veidotā ciḷņa dzīvā dramatika un skaistums. Apkārt ovālajam medaljonam vieni no greznākajiem un skaistākajiem manierisma ornamentiem Latvijas senajos dievnamos (5. attēls).

Centrālās daḷs sānos augstas, vīnogulāju apvītas kolonnas, kas balstās uz cokoliem ar serafimu galvām, norādot uz Dieva un debesu būtņu klātbūtni un dievkalpojuma (gan Dieva vārda pasludinājuma, gan Svētā Vakarēdiena) norises svētumu atbilstoši Jesajas vīzijai "Svēts, svēts, svēts ir Tas Kungs Cebaots" (Jes 6,3) par Dieva svētumu. Serafimu galvas redzamas arī kolonnu kapiteḷos (augšdaḷā).

darbnīcas māceklị? O. Spārītis savos pētījumos vairāk min 1648. gadu.
Manieriski izliekti eṇggeḷi ar dramatiskām grimasēm arī pašās retabla sānu rotājumu malās (10. attēls). Altāra malu stūros dažādas sejas (12. attēls), bet daḷu savienojumu vietās - fon Bēru un fon Maidelu dzimtu gerboṇu elementi.

Līdz galam neatbildēts jautājums ir par figūrām ar grāmatām retabla abu stāvu malās. Skaidrs, ka tie var būt tikai četri evanğélisti. Pirmā stāva malā starp kolonnām stāv divas vienkāršas apustuḷu figūras ar grāmatām (bet bez spārniem), bet otrā stāva malās - divas apustulu figūras ar spārniem, kas tālaika tēlniecībā ir l̦oti neparasti. Viena iespēja ir pirmā stāva figūras interpretēt kā Mateju un Marku, bet otrā stāva figūras - kā Lūkasu un Jāni22 Pirmā stāva sānu figūras ir vienkāršas, bez kādām specifiskām pazīmēm vai atribūtiem, tos var saistît ar jebkuru no mācekliem, tāpēc identifikācija iespējama tikai altāra teologiskā koncepta kontekstā. Uz Mateju un Marku lielā mērā balstās visa Sinoptisko evanggéēiju ${ }^{23}$ tradīcija, tāpēc tie atrodas pirmajā stāvā. Bet

${ }^{22}$ Mašnovskis 2005, 347. Tas nav pārliecinoši, ņemot vērā arī altāra retabla otrā stāva apustuḷu figūru simboliku.

${ }^{23}$ Tas ir vēlāku laiku (18. gs.) tehnisks apzīmējums trīs līdzīgajiem evaņgélijiem - MtEv, MkEv un LkEv. 


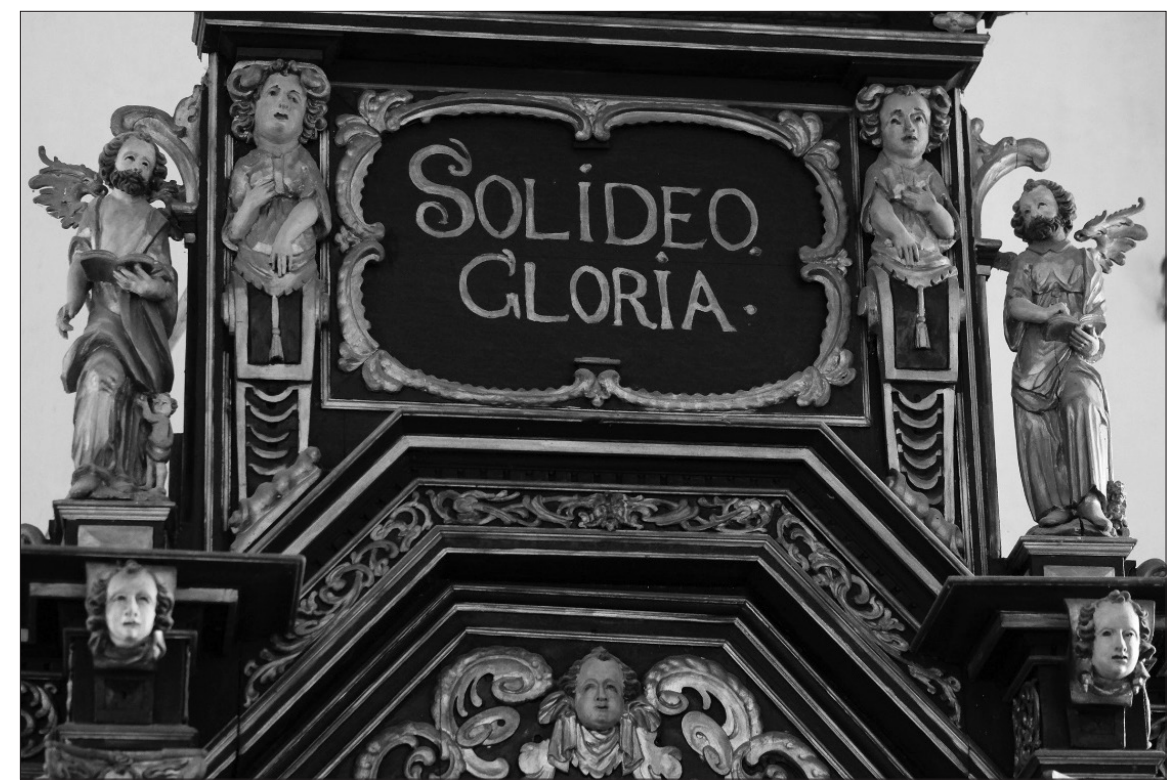

6. attēls. Ēdoles baznīcas altāra retabla otrais stāvs. Foto: Ralfs Kokins, 2018

kāpēc šie tēli ir daḷā, kurā attēlots Svētais Vakarēdiens (tā iestādīšanas vārdi atrodami MtEv 26, 26-28; MkEv 14, 22-24; LkEv 22, 19-20; 1Kor 11, 23-26)? Ja pirmajā stāvā ir attēlotas Jēzus apustulu Lūkasa (pa kreisi) un Jāna (pa labi) skulptūras, arī tas būtu teologiski saprotams - tādā veidā îpaši būtu izcelts Jēzus otrās atnākšanas apsolījums ("Lukāniskā dubultdarba" - LkEv un Acta - materiāls par Kristus parūsiju, tādējādi mudinot ḷaudis uz grēku nožēlu), kā arī ciln̄̄ izceltais Jēzus "Mīlais māceklis" (kurš pēdējo vakariņu laikā ir pie Jēzus krūtīm - JohEv 13, 1 u. c., pasvìtrojot tuvas un nepastarpinātas attiecības ar Pestītāju), kas ir JohEv īpašais materiāls.

Altāra retabla otrajā stāvā bagātīgā rotājumā kartuša ar uzrakstu SOLI DEO GLORIA, tās sānos 17. gs. tēlniecībā tik populārās hermas, ko vienkāršie dievlūdzēji var interpretēt arī kā engǵel̦us (6. attēls).

Tāpat jautājums ir par altāra retabla otrā stāva malās esošajām spārnotajām (!) apustuḷ figūrām ar grāmatām (kas simbolizē rakstīto un dievkalpojumā pasludināto Evaņgēeliju). Viena iespēja ir saskatīt, ka uz dzegām atrodas apustulı Mateja (pa kreisi) un Marka (pa labi) figūras (6. un 7. attēls). Matejam blakus redzams mazs bērniņš, jo tieši MtEv visvairāk no četriem evaṇgēelijiem minēts vārds "bērns".
Bet tikpat labi tās var būt arī evangéēlista Lūkasa (pa kreisi) un Jāṇa (pa labi) figūras, jo mazā bērniņa figūriņa pie apustuḷa kājām (pa kreisi) var norādīt uz Lūkasa evanĝ̣ēlija tekstā atrodamajiem vārdiem "Laidiet bērniṇus pie Manis un neliedziet tiem, jo tādiem pieder Dieva Valstība" (LkEv 18, 16). Bet vismulsinošākā figūra ir retabla otrajā stāvā pa labi. Parasti tā attēlo evangéēlistu Jāni (ar spārniem vai kā èrgli, jo pierakstījis "garīgāko" un dziḷāko no evanggélijiem), bet atkal mulsina maza lauvas skulptūriņa (!) pie figūras kājām - baznīcas mākslas vēsturēe arī 17. gs. tā attēloja evaņgèelistu Marku... Tajā pašā laikā Jāṇa figūra vislabāk sasauktos ar Soli Deo gloria, jo tieši Jāṇa evangéēlijā visvairāk runāts par godu un godību (JohEv 1.-13. nodaḷā runāts par Dieva godības eksoterisko atklāsmi pasaulei, kas ir mūžīgā dzīvība, savukārt 13.-21. nodaḷā par Dieva godības ezotērisko atklāsmi tuvākajiem mācekḷiem jeb "savējiem”, kas ir mīlestība). Vienlaikus, pieminot Dieva godu un godāšanu, tautai pirmā asociācija būs no Ziemsvētku notikuma enǵgeḷ slavas dziesmas Gods Dievam augstība an un miers ir virs zemes, un cilvēkiem labs prāts, kas ir evanggēlista Lūkasa īpašais materiāls (LkEv 2, 14).

Protams, ka vienkāršāk un saprotamāk būtu apustuḷu un evanǵgèlistu tēlus "lasīt" 


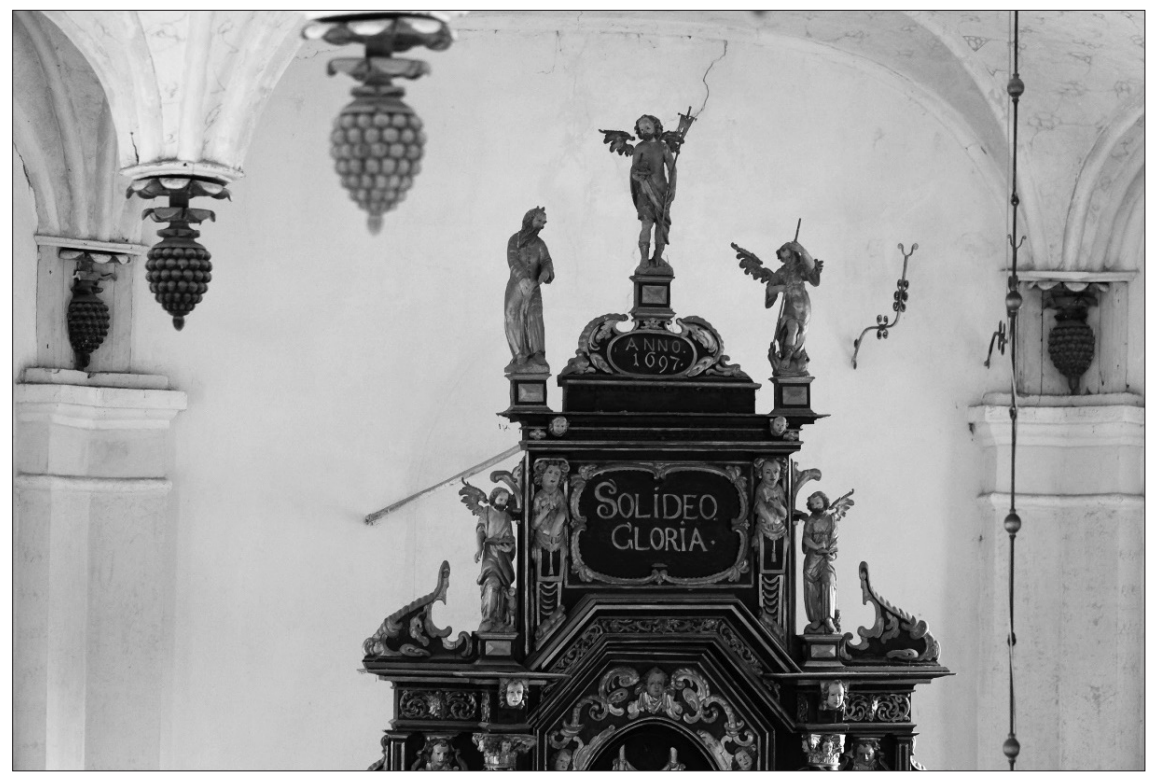

7. attēls. Ēdoles baznīcas altāra retabla augšdaḷa. Foto: Ralfs Kokins, 2018

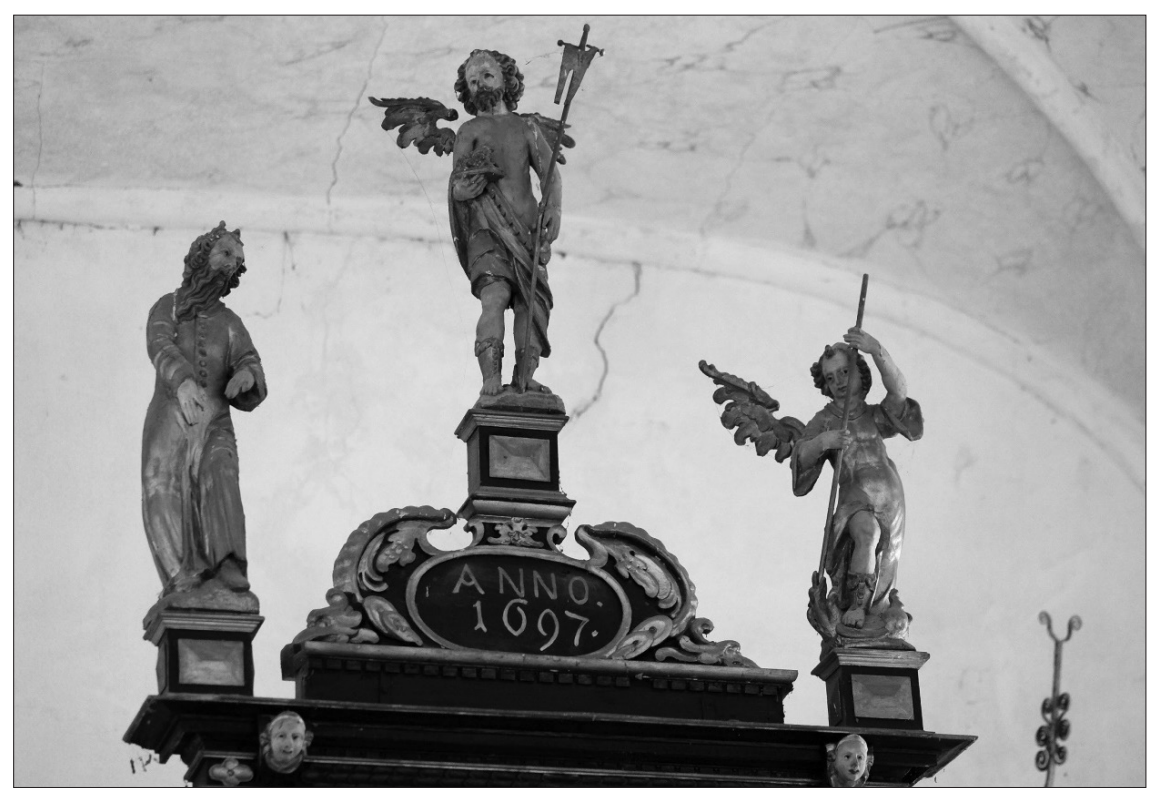

8. attēls. Ēdoles baznīcas altāra retabla augšdaḷas figūras. Foto: Ralfs Kokins, 2018

Jaunās Derības kanonisko evanggèèiju secībā (MtEv - MkEv - LkEv - JohEv), sākot ar retabla otro stāvu uz leju. Tomēr figūru mīklainais izpildījums nekādā veidā nel̦auj izdarīt viennozīmīgus secinājumus. Ļoti iespējams, ka autors vai nu apzināti, vai brīvas mākslinieciskas un kompozicionālas intereses dẹl (lejā figūras bez spārniem, augšā - ar spārniem) apzināti nojaucis apustulu un evangéēlistu nepārprotamas atpazīstamības robežas. Ļoti iespējams arī, ka vismaz apustuḷu figūrās neslēpjas šì altāra teologiskais vēstījums.

Daudz neskaidrību rodas altāra retabla augšējās (“debesu”) daḷas (8. attēls) figūru 


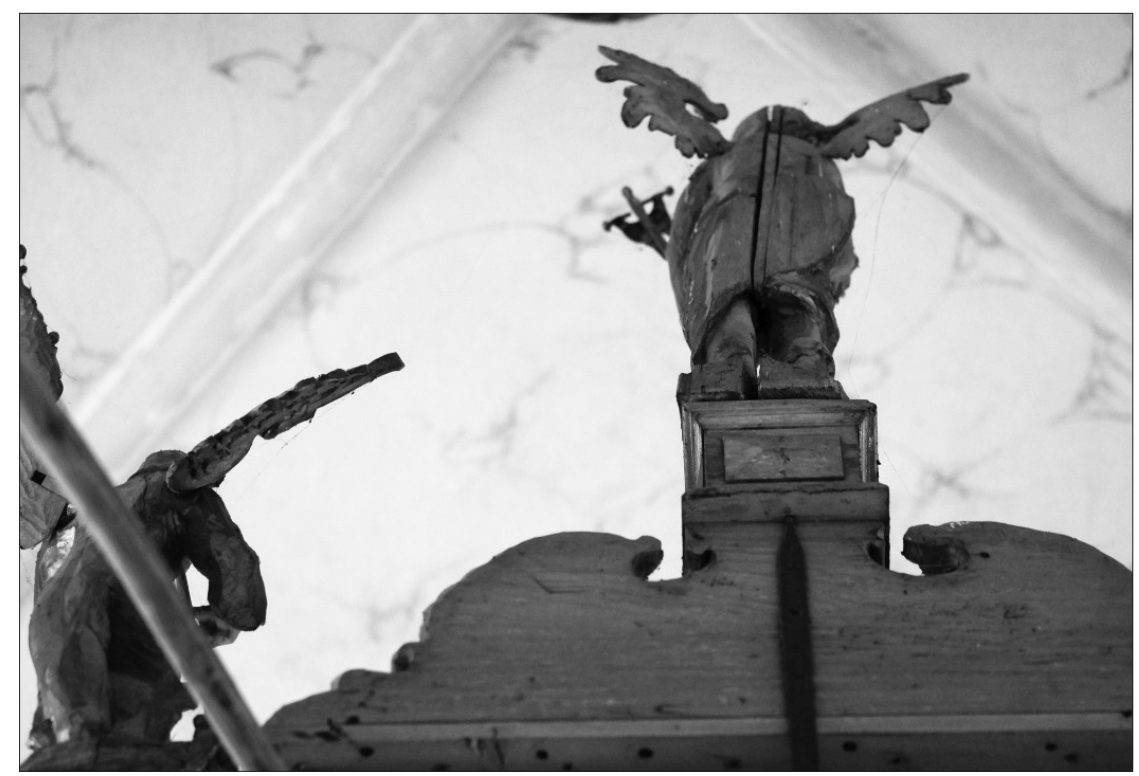

9. attēls. Ėdoles baznīcas altāra retabla aizmugure. Foto: Ralfs Kokins, 2018

skaidrojumos. Centrā, ovālā medaljonā uzraksts $A N N O 1697 .{ }^{24}$, kas ir nevis altāra darināšanas, bet gan nokrāsošanas gads. Sākotnēji 1647./1648. gada altāris bijis nekrāsots (līdzīgi kā Ugāles baznīcas 1701. gadā būvētās 28 reǵistru divu manuāḷ (Kuldīgas ērǵeḷūvētāja Kornēliusa Rāneusa un Ventspils koktēlnieka Mihaela Markvarta) fenomenālās èrǵeles), un tikai 1795. gadā Ulrihs fon Bērs to licis nokrāsot atbilstoši 17. gs. beigu modei Kurzemē (melns ar zeltu). Šo faktu pierādot arī veiktās krāsojuma slānu zondāžas ${ }^{25}$.

Retabla augšdaḷā redzamas trīs iespaidīgas figūras. Pašā augšā augšāmceltā pasaules Pestîtāja (Salvator Mundi) figūra. Augšāmceltais Kristus netipiski attēlots l,oti cilvēcisks, bet ar spārniem (kā "en,géeliska" būtne), šādā savdabīgi vienkāršā veidā pasvītrojot Viņa uzvaru pār pašu nāvi. Uz šo uzvaru norāda arī karogs Viņa kreisajā rokā. Labajā rokā Viņš tur jēriņa skulptūru, ar to uzsvērts, ka Viņš ir tas Dieva jērs, kurš ticis upurēts par cilvēku grēkiem ("Redzi, Dieva Jērs, kas nes pasaules grēkus", JohEv 1:29), lai izpirktu mūsu vainu,

${ }^{24}$ E. Kiploks 1697. gadu uzskata par šīs baznīcas pabeigšanas gadu (Kiploks 1987, 406).

25 Mašnovskis 2005, 347. salīdzinātu mūs ar Dievu, kā arī izglābtu mūs no gaidāmās Dieva tiesas ar tai neizbēgami sekojošo mūžīgo sodu un pazušanu.

Nevienā man zināmajā aprakstā vai pētījumā netiek identificētas un skaidrotas altāra augšējās daḷas trīs figūras. V. Mašnovskis savas enciklopēdijas 1. sējumā neprecīzi norāda, ka attēloti ir apustuḷi ar spārniem ${ }^{26}$, citi autori min tikai vispārīgi enggeḷu un apustuḷu figūras altārī.

Labajā pusē redzama figūra ar spārniem, kreisās puses figūrai spārnu nav (tā atšķiras no abām pārējām arī ar ķermeņa pozu/izliekumu). Spārnotā figūra labajā pusē varētu būt ercenggelis Mihaēls, kurš uzveic veco pūḳi velnu, to nogāzdams no debesīm (Apok 12, 7-10) - figūra attēlota ar šķēpu, bet zem tās kājām redzams nedaudz vienkāršots pūḳis (tā rîklē ir šḳēpa gals). Kreisās puses figūra ir vai nu Mozus (jo Kristus darbs un Evangéēlijs ir saprotams vienīgi Vecās Derības likuma kontekstā), vai pat Ārons vai Melhisadeks (arī tas ticams, ņemot vērā Svētā Vakarēdiena motīvu altāra centrālajā daḷā $)^{27}$. Šai figūrai nav bijuši

26 Mašnovskis 2005, 347.

27 Gen 14, 18: "Un Melhisedeks, Salemas k̦ēniņš, iznesa vīnu un maizi; viňš bija visuaugstā Dieva priesteris." 


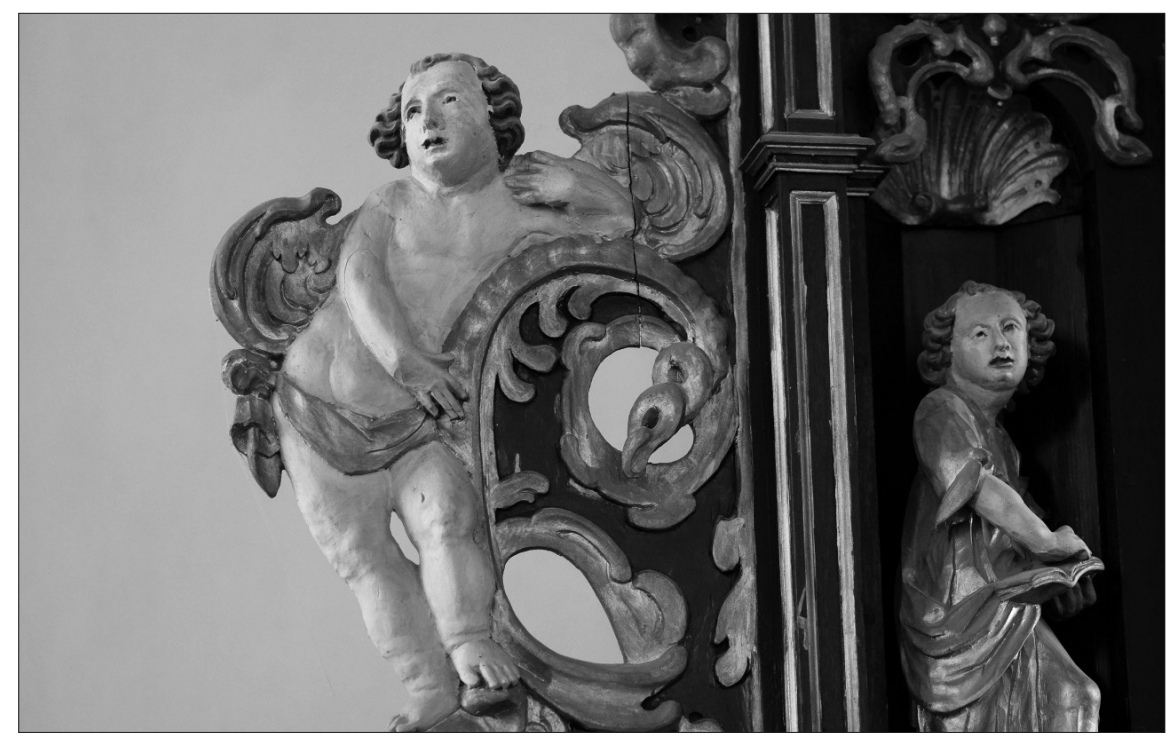

10. attēls. Ēdoles baznīcas altāra sānu figūras. Foto: Ralfs Kokins, 2018

spārni, bet izskatās, ka tai rokās kādreiz varētu būt bijuši bauslības (likuma) galdiṇi, tādā gadījumā šī figūra identificējama kā Mozus (caur kuru dots Dieva likums). Tieši Mozu visbiežāk sakrālajā mākslā attēlo ar dramatisku matu sakārtojumu, kāds redzams kreisās puses figūrai.

No aizmugures altāris ir slikti nostrādāts, nekrāsots, tāpat arī retabla augšdaḷas tēli (9. attēls) - brīvi stāvošais altāris atrodas no draudzes telpas ar sētu norobežotā altārtelpā un nav bijis paredzēts skatīšanai no otras puses. Vairums koka tēlu ir sliktā stāvoklī, tajos ir gan ķirmju bojājumi, gan arī (pārsvarā) dažādas plaisas no temperatūras un mitruma svārstībām dievnamā.

Zeltījums uzklāts vairākās kārtās, pati vecākā, tikai vietām redzamā (apakšējā) kārta varētu būt īsts zeltījums (ḷoti atškiriras no vēlāk uzklātajām bronzas kārtām). Figūru īpatnība ir to acis - lai panāktu to dzìvumu, acu zīlītes veidotas melni krāsotu dobumu veidā.

Ap altāri tālaika dievnamiem visnotal ierasta altārsētiņa (ar greznu koka rotājumu), kas paredzēta maksimāli 12 dievgaldniekiem.

Tomēr visgrūtākie jautājumi saistās ar altāra un visas iekārtas teolog̣isko vēstījumu.

MEMENTO MORI ir atgādinājums gan mācītājam, gan aristokrātiem, gan arī visai draudzei, ka mēs visi šeit esam tikai īsu brīdi un pagaidām. Mēs visi Dieva priekšā esam vienādi (vienādās pozīcijās neatkarīgi no sociālā stāvokḷa), mēs dzīvojam tikai no Dieva žēlastības, un viss, uz ko ceram mūžǐbā, ir atkarīgs no Kristus darītā un Dieva žēlastîbas. Laiks paiet l,oti ātri, visas lietas dzīvē ir tik trauslas un pārejošas, tāpēc sirsnīgi jādomā par mūžību, nākot pie Dieva - nožēlojot grēkus un atgriežoties no visa nepatiesā un launā. Atslēga mūžības iemantošanai ir dievkalpojuma svinībās (Svētā Vakarēdiena motīvs centrālajā ciln̄̄ starp apakšējo Memento mori un augšējo Soli Deo gloria), kas norāda arī uz lielo, priecīgo Debesu kāzu mielastu.

MEMENTO MORI tieši sasaucas arī ar SOLI DEO GLORIA altāra retabla otrajā stāvā - mēs esam mirstīgi, bet Dievs dzīvo un valda no mūžības uz mūžǐbu. Savā mirstīgumā un tik skaudrajās robežās esam aicināti pacelt savas acis uz Dievu un Viņa mūžīgo godību. Ja ticam uz Dievu, arī mēs drīkstam būt no mūžǐbas uz mūžību. Viss, uz ko mēs ticam un ceram, ir tikai vienīgi Dievā. Uzmanīgs vērotājs altāra elementos atpazīs luteriskās reformācijas pamatprincipus, kas izriet no Jaunās Derības mācības par nabaga dzīvei, nāvei un pazušanai nolemtu grēcinieku taisnošanu ticībā neatkarīgi no likuma darbiem (Rom 3, 28), ko dēvē par Taisnošanas 


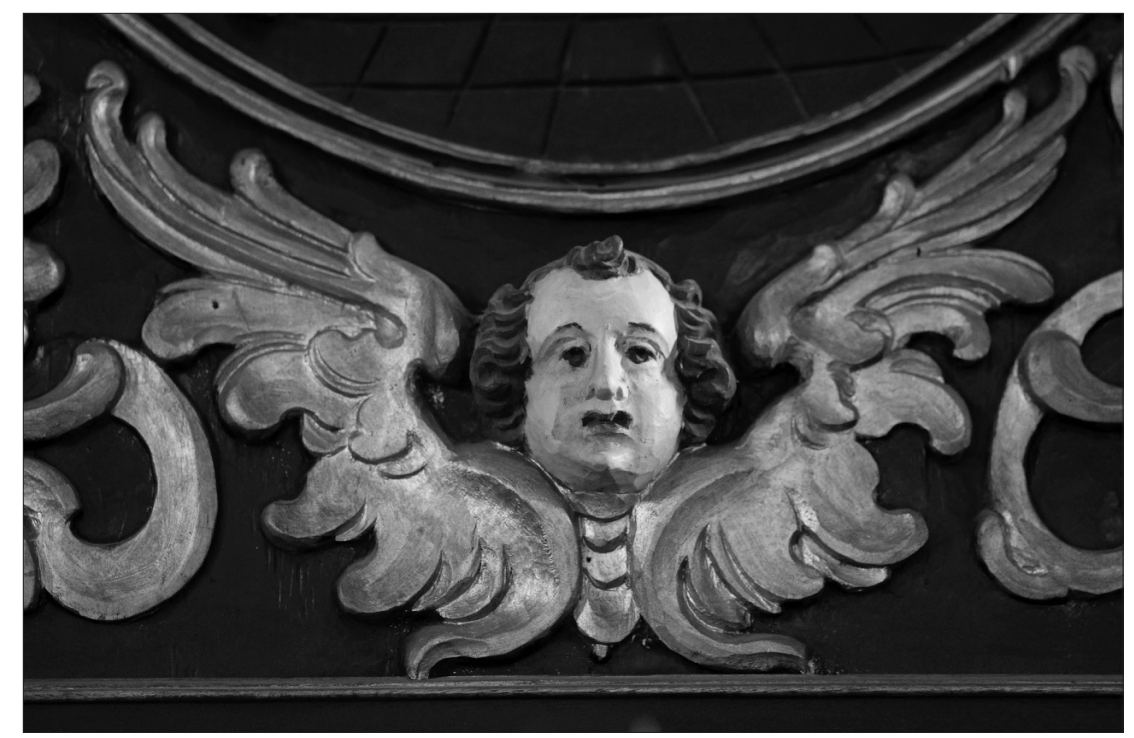

11. attēls. Ēdoles baznīcas altāra centrālās daḷas rotājums. Foto: Ralfs Kokins, 2018

mācību ${ }^{28}$. SOLI DEO GLORIA noteikti ir arī summējums četriem labi zināmiem bibliskajiem pamatprincipiem, kas īpaši tika izcelti luteriskajā ticībā: Sola Fide (tikai ticība) glābšanu no launuma un nāves fatālās varas cilvēks sasniedz tikai caur ticību, nevis likuma darbiem (vai caur centību); Sola Gratia (tikai žēlastība) - Dieva žēlastība, kas mums tiek izrādīta Jēzū Kristū, ir vienīgais pamats cilvēka glābšanai, nevis kādu svētu cilvēku, priesterisku amatu vai institūciju nopelns; Solus Christus (tikai Kristus) - Kristus ir vien̄̄gais pamats kristīgai ticībai un baznīcai, Viņam nelīdzinās neviena cita persona vai vara; Sola Scriptura (tikai Raksti) - tikai Jaunās Derības 27 kanoniskās grāmatas uzskatāmas par Evaņgélija avotu un normu un nevis vēlāku laiku baznīcas leǵendas, tradīcijas, tautas ticējumi un citas lietas ${ }^{29}$.

28 Par Taisnošanas mācību (taisnošanu ticībā) skat. luterisko ticības apliecību pamatdokumentus, sevišḳi t. s. Vienprātības grāmatā (Liber Concordia) ietverto Augsburgas ticības apliecības (CA) apologijas (1531) artikulu Par taisnošanu (Liber Concordiae 2001, 84-103).

29 Brunner 2002, 221; šie četri principi l,oti daudz aprakstīti un analizēti arī neskaitāmos citos pētījumos par luterisko reformāciju.
Lai arī Ėdoles altāra centrā atainots Svētais Vakarēdiens, būtībā viss teoloǵiskais uzsvars tiek likts uz Kristus darīto mūsu glābšanas labad caur savu vietniecisko ${ }^{30}$ krusta nāvi, mūsu vietā izciešot sodu par mūsu grēkiem ${ }^{31}$.

Tikai luteriskā reformācija vienkāršajai tautai iedeva Svētos Rakstus tautas valodā, aizejot no klerikālās latīṇu valodas lietojuma dievkalpojumos. Ko nozīmē altāra centrā attēlotais Svētais Vakarēdiens šīs baznīcas celtniecības vēstures un Sühnekirche koncepta sakarā (lai izpirktu vainu)? Arī augšāmceltais Kristus altāra augšdaḷā ir pārsteidzoši līdzīgs citiem tēliem, sevišḳi apustuḷiem, izceḷot ne tikai Viṇa dieviškīību, bet arī patieso cilvēcību (Jāṇa evaṇgélija prologs!). Dieva Dēls ir nācis šajā pasaulē kā patiess cilvēks, kā draugs un brālis. Ikvienam ticīgajam ir zināms spilgtais Kaina un Ābela stāsts (Genesis 4, 1-16) par brāḷa slepkavību neizskaidrojama l̦aunuma un greizsirdības dēḷ. Tas ir arhetipisks stāsts, kurš skar lielos un sāpīgos dzīves un attiecību jautājumus. Atbilde uz tiem ir Kristus, un atbilde

30 Par Jēzus nāves vietniecisko raksturu ḷoti daudz teoloǵisku pētījumu, viens no labākajiem: Hengel 1980, 1-25, 135-147.

31 Luteriskās (bibliskās) Krusta teologijas pieteikumu skat. Luther 1983; arī Moltmann 1972. 


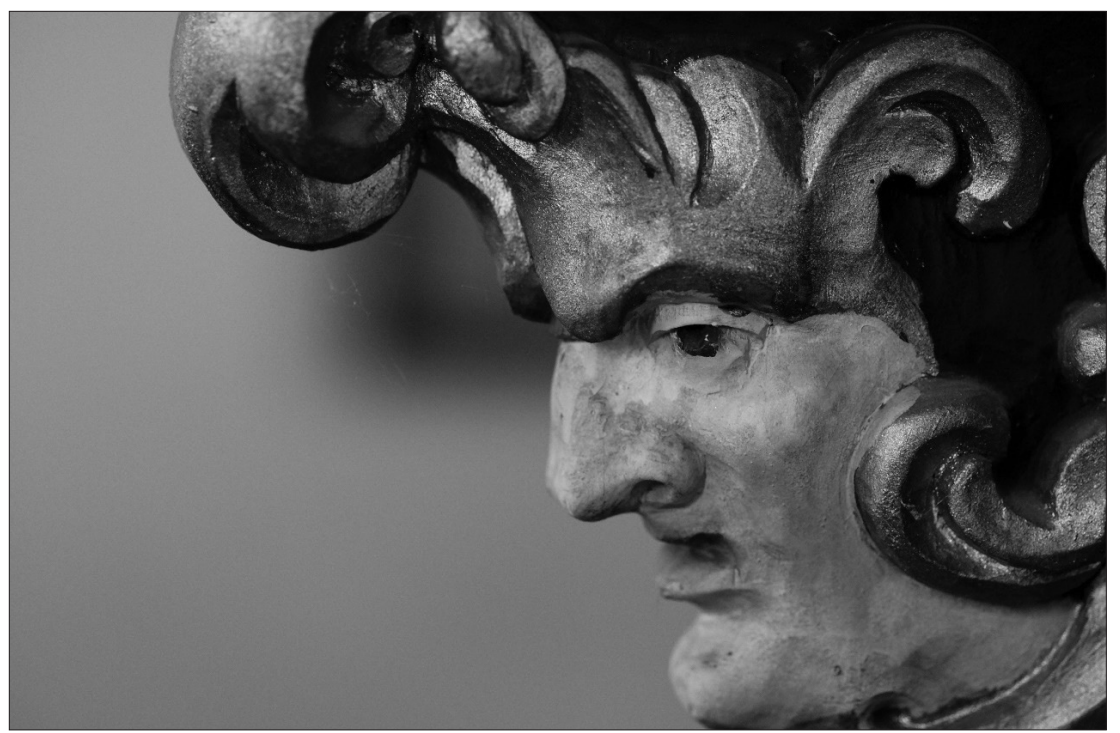

12. attēls. Ēdoles baznīcas altāra retabla pirmā stāva stūra rotājums. Foto: Ralfs Kokins, 2018

slēpjas arī dievkalpojuma drāmā un mistērijā, kura centrā ir gan Dieva Vārda pasludinājums, gan Svētais Vakarēdiens ${ }^{32}$. Tieši tādēl skaistajā Ēdoles baznīcas iekārtā, seviškíi altāra tēlos un rotājumos, redzamas tik daudzas sejas ar izteikti dramatiskām grimasēm. Vecās Derības stāstā taisnā Ābela asinis brēc uz debesīm, bet Jaunajā Derībā tiek nogalināts Jēzus, kurš ir bez grēka un neko l̦aunu nav darījis. Cilvēki ar Jēzu izrīkojās tāpat kā Kains ar savu brāli $\bar{A}$ belu, bet Kristus nevainīgi izlietās asinis nes mums svētību, ir vienīgais mūsu gods un greznība, jo gādā mums pestīšanu. Nav tāda grēka, kuru Dievs nevarētu piedot Kristus nopelna, Viņa vietnieciski samaksātā soda dēl, ja vien grēcinieks to patiesi nožēlo un atgriežas, cerot uz Dieva žēlastību Pastarajā tiesā.

Kancele (13. attēls) atrodas draudzes telpas kreisajā pusē pie sienas, tās uzeja veidota altārtelpā, bet pati kancele izbīdīta ārpus tās, jau draudzes telpā, tādējādi izceḷot no Dieva (Kristus no Debesīm) nākušo Evaṇgēliju jeb Labo vēsti, kas tiek pasludināta un skaidrota sprediķ̄î.

32 Par Jēzus pēdējām vakariņām (Passā mielastu) ar saviem mācekḷiem, kā arī no tām izrietošajām baznīcas Sv. Vakarēdiena svinībām skat. Theissen, Merz 1996, 366-387.
Nišās starp kolonnām Salvator Mundi (Pasaules Pestītāja) un Jēzus mācekḷu/apustuḷu ciln̄̄ veidotas figūras ar svētā apustuḷa vārdu zem katras no tām. Kanceles korpusa nišās novietotas (uzskaitījums no kreisās uz labo pusi) Sv. Andreja (S. Andreas), Sv. Pāvila (S. Paulus), Sv. Jēkaba (S. Iacobi v. s.), Salvator Mundi un Sv. Pētera (S. Petrus) figūras, bet kanceles uzejas nišās - Sv. Jāņa (S. Iohannes), Sv. Simaña (S. Simones) un Sv. Bartolomeja (S. Bartolomeus) figūras. Gandrīz puse no Jēzus 12 mācekḷiem (uzskaitīti MtEv 10, 2-4) nav attēlota (nav attēloti: Filips, Toms, Matejs, Tadejs un Jūda). Kādi bijuši konkrētu mācekḷu izvēles kritēriji kanceles mazo izmēru dēl (atškiirībā no Zlēkām), nav vairs noskaidrojams (Filips, Toms un Matejs ir vienlīdz svarīgi ar attēlotajiem Andreju, Sīmani un Bartolomeju).

Kancele ir neierasta arī ar to, ka Salvator Mundi figūra ir novietota nevis ierastā veidā korpusa centrā pret draudzi ( $k \bar{a}$ tas redzams Ugālē, Zlēkās un citur), bet gan pret rokoko stilā izrotāto Kungu ložu altārtelpas labajā pusē, pasvītrojot Dieva un Kristus žēlastîbā pieškiirtās privilēgijas aristokrātiem gādīgi (kristīgi) pārvaldīt šīs puses dzimțaudis.

Neierasts ir fakts, ka kanceli balsta nevis Mozus ar bauslības (likuma) galdiņiem (tādējādi pasvītrojot Likumu un Evanggéèliju), kā tas 


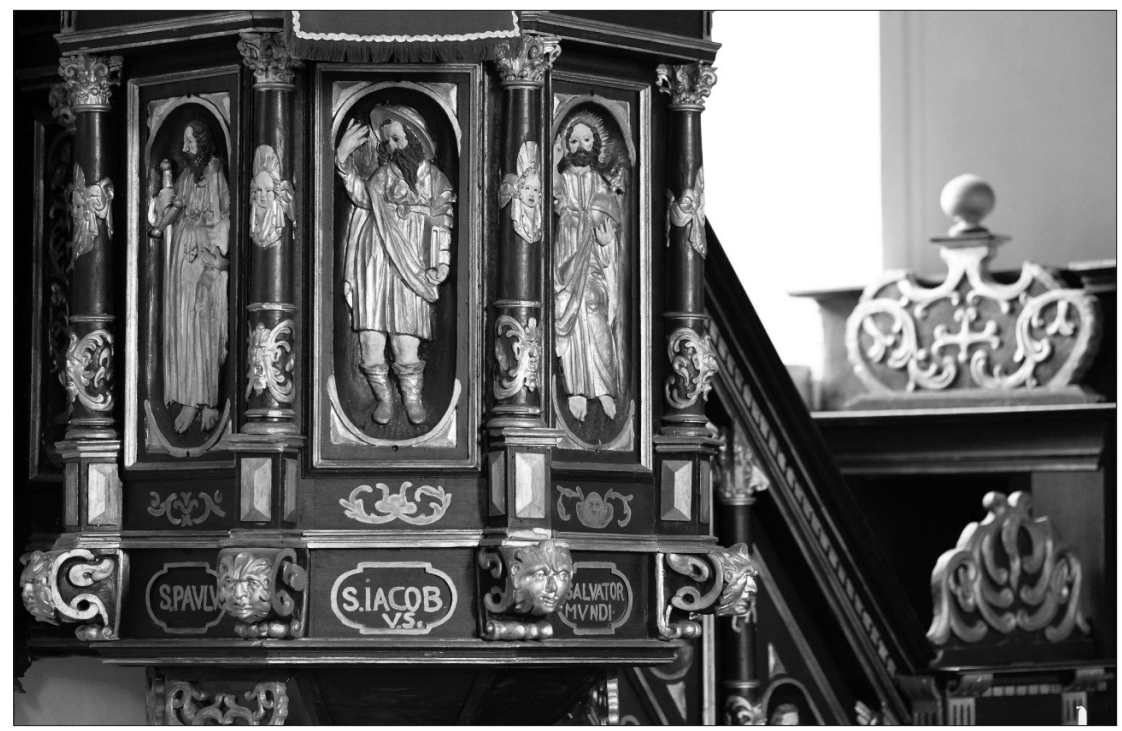

13. attēls. Ēdoles baznīcas kancele. Foto: Ralfs Kokins, 2018

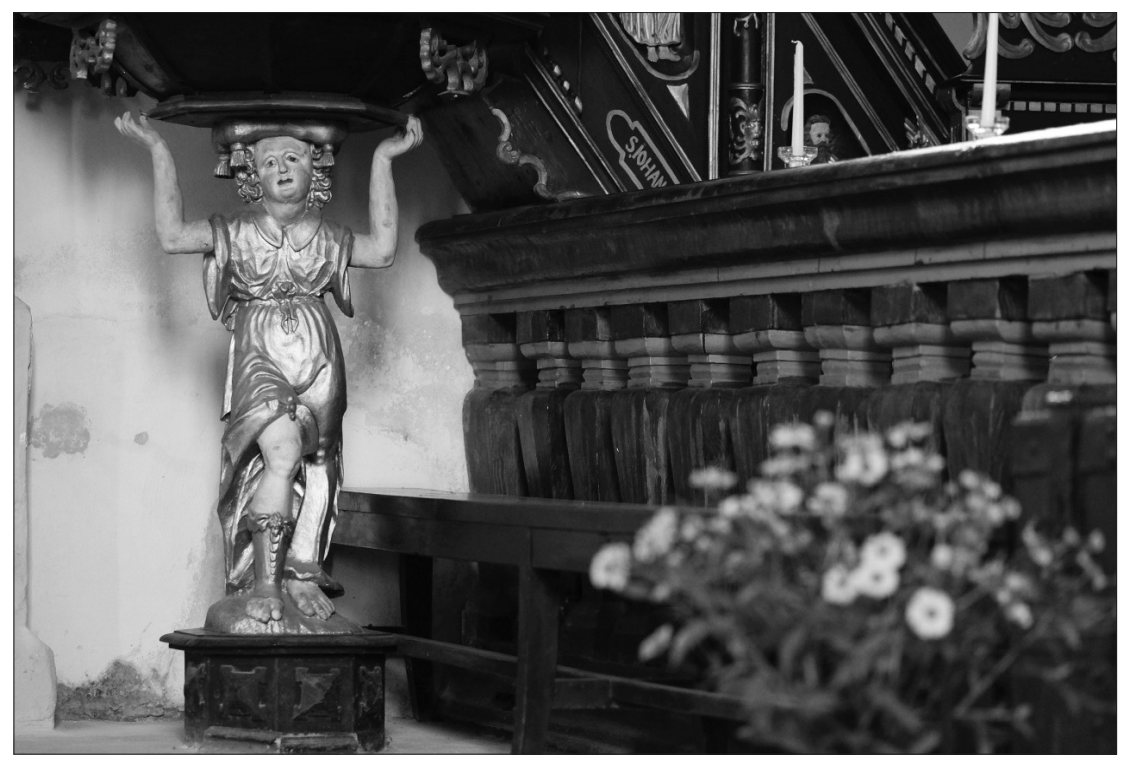

14. attēls. Ėdoles baznīcas kanceles balsts. Foto: Ralfs Kokins, 2018

ir vairumā tālaika baznīcu (piem., Ugālē), bet gan uz astoņstūra postamenta stāvošs skaists enggeelis, kurš paceltās rokās tur greznu spilvenu uz galvas (14. attēls).

Eṇǵelim bijuši arī spārni, kas kādu remontu laikā pazuduši, tā ka uz tā muguras redzami spārnu pamatu stiprinājumu caurumi, kas aizdarīti ar raupjām koka tapām (15. attēls).
Pārsteidzoši līdzīgs (gandrīz identisks), loti skaists engelis ar spilvenu uz galvas balsta arī Zlēku baznīcas kanceli (16. attēls). Salīdzinot abus engǵeḷus, Brēmenes tēlnieka F. Hopenšteta 1645,-1652. gadā darinātais Zlēku enggélis ir krāsains un labāk nostrādāts (Zlēku baznīcas filigrāni darinātā iekārta laikam ir viskrāšņākais manierisma stila 


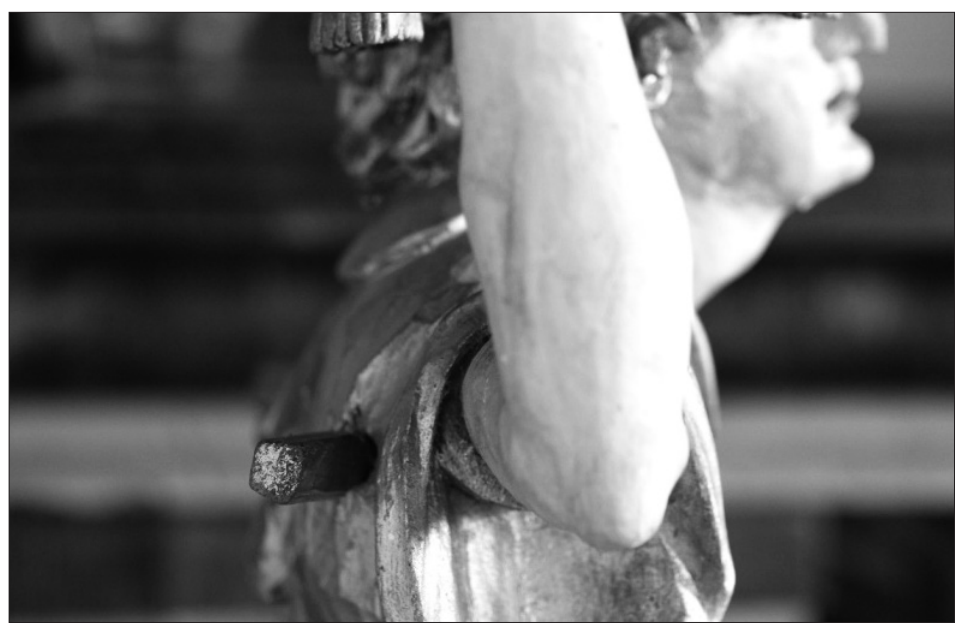

15. attēls. Ēdoles baznīcas kanceli balstošā eṇgeḷa spārnu vietas. Foto: Ralfs Kokins, 2018

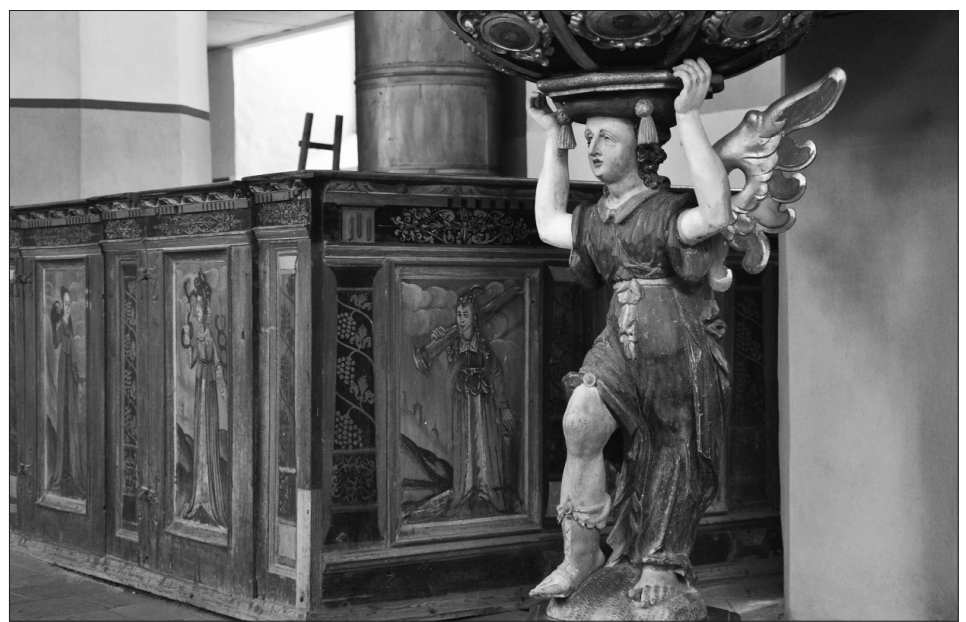

16. attēls. Zlēku baznīcas kanceli balstošais eṇgelis. Foto: Ralfs Kokins, 2013

darinājums Latvijas dievnamos; skat. 16. un 17. attēlu). Līdz ar to rodas jautājums par koktēlnieku T. Heinca un F. Hopenšteta nepārprotamo saistību un savstarpējo ietekmi (vai ar̄i abu iespaidošanos no kādiem tālaika slavenākiem koktēlniecības darbiem), kas līdz šim nav argumentēti atbildēts ${ }^{33}$.

${ }^{33}$ V. Mašnovskis atsaucas uz O. Spārǐša minējumu, ka tieši Ëdoles iekārtas autors T. Heincs varētu būt ietekmējis F. Hopenšteta 1645.-1652. gadā tapušo Zlēku baznīcas iekārtu (Mašnovskis 2007, 442). Man ticama šḳistu arī iespēja, ka abi šie autori ietekmējušies no kādiem izciliem tālaika kokgriezumiem.
Ēdoles baznīcas kanceles korpusa stūros - mākslinieciski dažādu seju atveidojumi (18. un 19. attēls).

Kanceles jumtiňš ir neierasti grezns un savdabīgi veidots (20. attēls). Uz profilèta astonstūru pamata, kas rotāts ar engégeḷ galviṇām tā stūros un bagātīgiem, reljefiem rotājumiem, balstās ḷoti grezna un sarežǵîiti veidota laterna ar trīs eng̣eḷu figūrām (ar kolonnu, ar krustu un ar knaiblēm), kas varētu norādìt uz š̄is baznīcas celtniecības un iekārtošanas nolūku, paklausot paša Kristus aicinājumam - pasludināt visām sabiedrības kārtām Kristus Evaņgēēiju, vest l̦aužu dvēseles pie Jēzus un visus izglābt no mūžīgās nāves un pazušanas. 


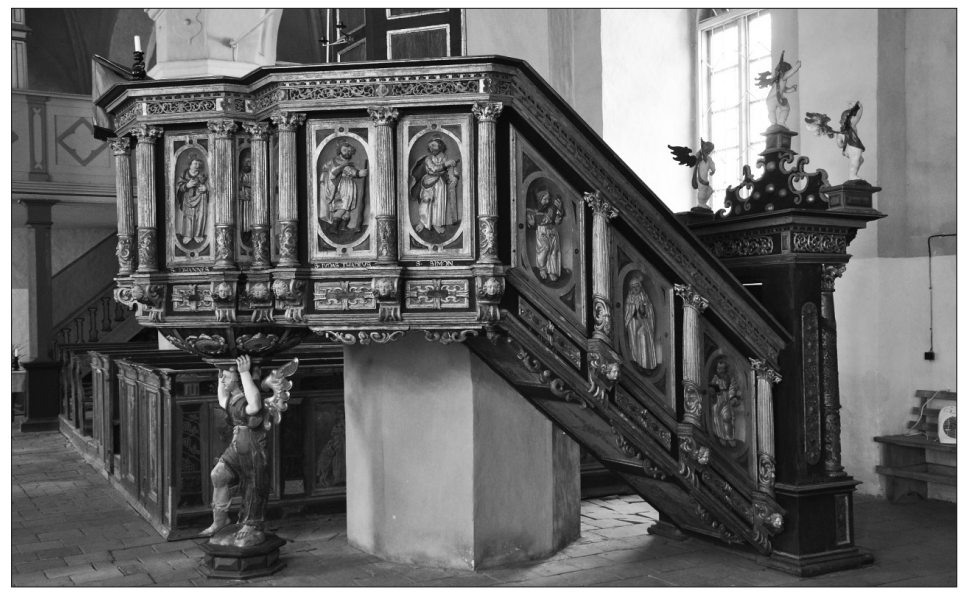

17. attēls. Zlēku baznīcas kancele. Foto: Ralfs Kokins, 2013

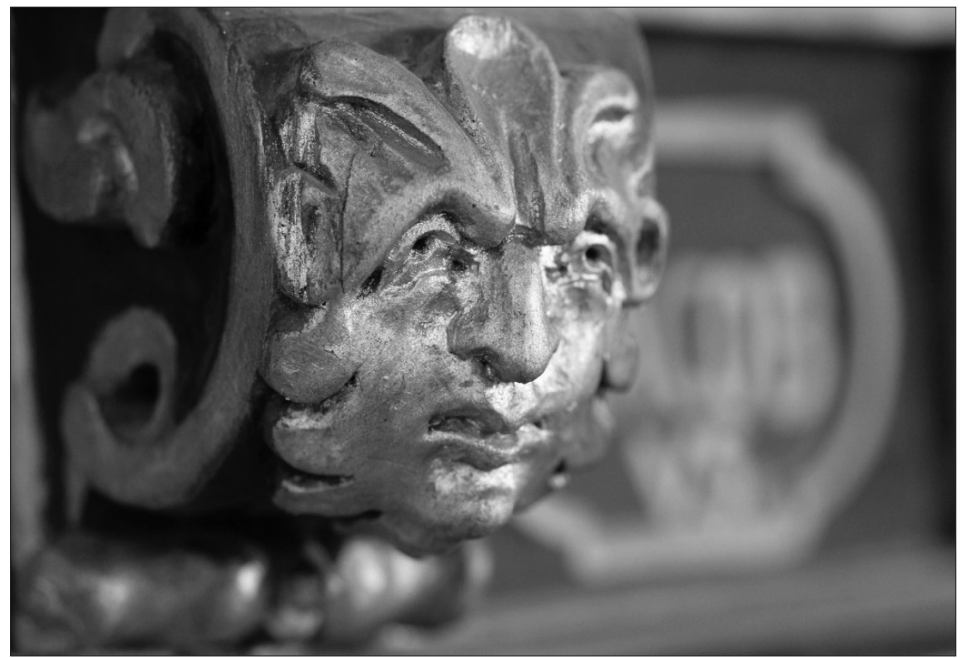

18. attēls. Ēdoles baznīcas kanceles stūra rotājums. Foto: Ralfs Kokins, 2018

Kanceles jumtina smaile (ažūra volūtu konstrukcija ar septinu engẹelu galvām pamatnes stūros, kas norāda uz JohApk 8, 2 minētajiem septiņiem enggẹliem, septiņām bazūnēm) rada gaisīga viegluma iespaidu. Smailes galā manierisks eṇgelis ar divām bazūnēm (līdz̄ịs kanceli balstošajam enggelim; 21. attēls) simbolizē Jāṇa apokalipsē atrodamos pēdējo laiku notikumus (JohApk 8. un 11. nod.). Tas ir atgādinājums par laika īsumu un aicinājums ikvienam atgriezties, uzklausot dievkalpojumā sludināto Dieva vārdu.

Loti interesants ir ar kanceles uzeju savienotais biktssols (redzams 4. attēlā), kas pieskanots kancelei un altārim (melns ar zeltu) un atgādina karieti. Tas gan ir tikai 18. gadsimta otrās puses, iespējams, Josefa Slavičeka darinājums ${ }^{34}$. Biktssola korpuss ir horizontāli izliekts, tā korpusu veido četras korintiskā ordera kolonnas ar bagātīgi rotātiem cokoliem, starp kolonnām interesanti veidoti "logi" ar 18. gs. otrajai pusei tik raksturīgajām skaistajām formām un rotājumiem, piedevām malējie "logi" veidoti spogul̦simetrijā. Biktssola

34 Mašnovskis 2005, 347 atsaucas uz Imanta Lancmaña ekspertīzi, ka autors varētu būt Josefs Slavičeks, kurš Kurzemē darbojies no 1757. līdz 1784. gadam. Biktssolu pasūtinājuši Hermanis Frīdrihs fon Bērs un Juliāna fon Bēra. 


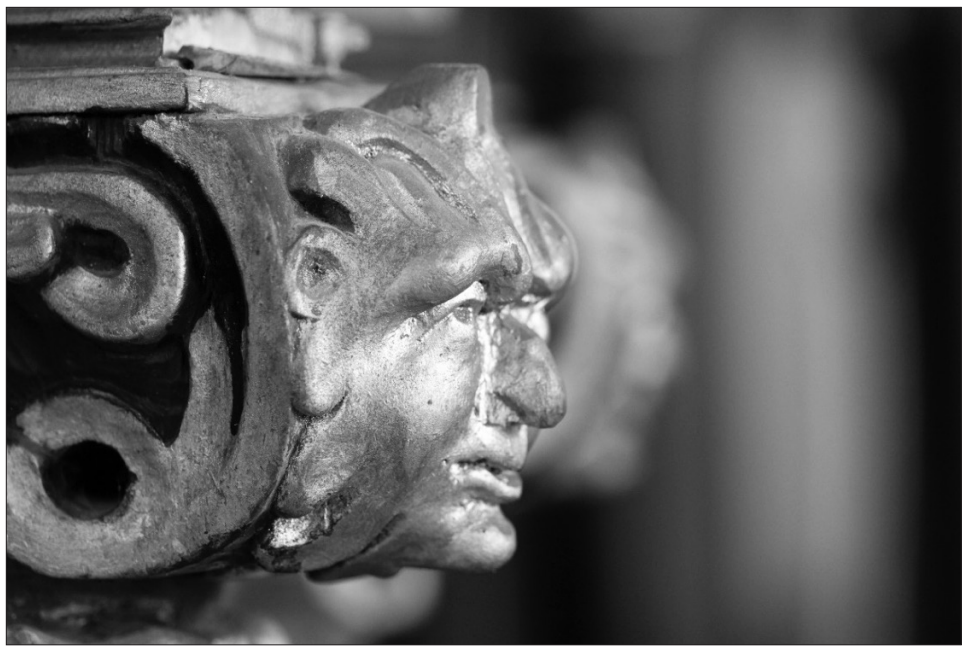

19. attēls. Ēdoles baznīcas kanceles stūra rotājums. Foto: Ralfs Kokins, 2018

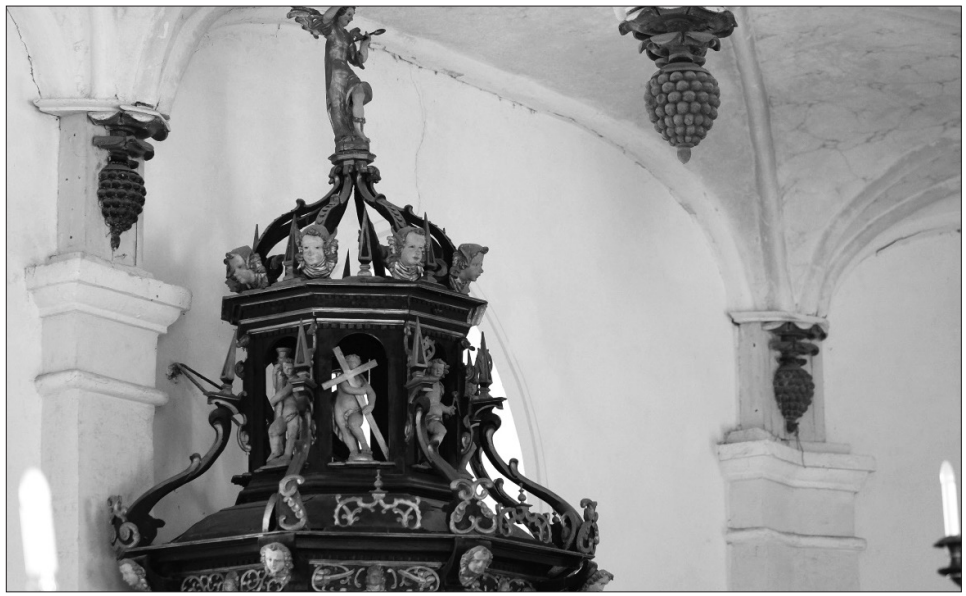

20. attēls. Ėdoles baznīcas kanceles jumtiņš. Foto: Ralfs Kokins, 2018

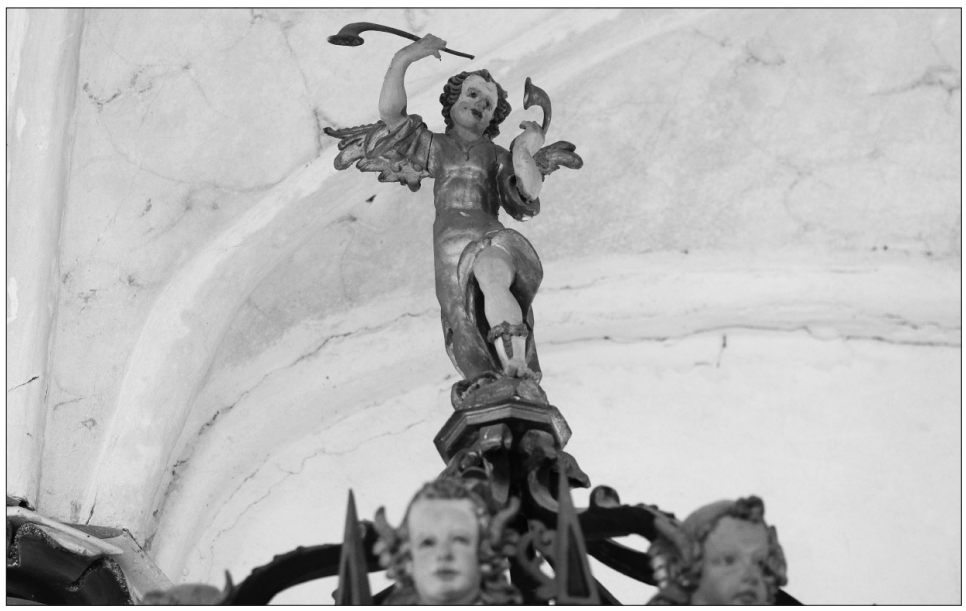

21. attēls. Ēdoles baznīcas kanceles jumtiṇa augšdaḷa. Foto: Ralfs Kokins, 2018 
augšdaḷa grezni rotāta ar dažādām Juliānas un Hermaņa fon Bēru monogrammām, bet tā augšdalıas centrā - l̦oti grezns, profilēts, filigrāni griezts fon Bēru dzimtas ǵerbonis (ar diviem melniem lāčiem).

Katrā zin̄ā Ēdoles baznīca un tās skaistā, tik savdabīgi dramatiskā iekārta slēpj vēl daudzus noslēpumus un neatbildētus jautājumus. Visa baznīcas telpa ir ar spēcīgu un daudzdimensionālu teoloǵisku vēstījumu, tā cilvēku uzrunā simbolu un līdzību valodā, norādot uz dzīves skaistumu un traǵiku vienlaikus, kā arī liekot aizdomāties par visu lietu trauslumu un issumu mūžības priekšā, aicinot nožēlot ḷauno un meklēt dzīvo Dievu. Šis īpašais dievnams ir loti maz pētīts un aprakstīts, tas vēl joprojām gaida nopietnu un kontekstuālu izpēti (sava laikmeta Rietumu sakrālās mākslas un teologisko ideju kontekstā), kas būtu jāveic vairāku zinātņu nozaru speciālistiem kopā.

\section{VĒRES}

Behr, U. B. von (1979) Edwahlen und die Behrsche Ecke in Kurland. Selbstverlag.

Brotze, J. C. (1997) Prospect von Edwahlen in Kurland, dem Etatsrath von Bähr gehörig [die Ansicht], 1795. Sammlung verschiedner Liefländischer Monumente, 7. sēj., I d.: Johana Kristofa Broces (1742-1823) Baltijai veltītie zìmējumi ar aprakstiem. Rīga : LU AB. Pieejams: http://www3.acadlib.lv/brocel (03.09.2018.).

Brunner, E. (2002) Dogmatics: The Christian Doctrine of the Church, Faith \& the Consummation, Vol. III. Transl. by D. Cairns, T. H. L. Parker. Cambridge : James Clarke \& Co.

Campe, P. (1930) Die Kirchenglocken Lettlands von ältester Zeit an bis zum Jahre 1860 und ihre Giesser. Acta Universitatis Latviensis (Latvijas Universitātes Raksti), Arhitektūras fakult. sēr., I sēj., 1.

Grīns, A. (red.) (1931) Kultūras un tikumu vēsture, II sēj. Rīga : Grāmatu draugs.

Grosmane, E. (2001) Tēlniecības darbnīcas Kurzemes un Zemgales hercogistē 17. gs. otrajā pusē - 18. gs. sākumā. Ventspils muzeja raksti, 1. d., 186-205.

Hengel, M. (1980) Der stellvertretende Sühnentod Jesu. IKZ 9.

Ķiploks, E. (1987) Dzimtenes draudzes un baznīcas: Ev.-lut. baznīcas un draudzes Latvijā. Minneapolis : Latviešu ev.-lut. baznīcas Amerikā apgāds.

Liber Concordiae: Luterāņu ticības apliecības (2001) Rīga : Augsburgas institūts.

Luther, M. (1983) Die Botschaft des Kreuzes. Bearb. von Horst Beintker. Berlin.

Mašnovskis, V. (2005) Latvijas luterāņu baznīcas: vēsture, arhitektūra, māksla un memoriālā kultūra, 1. sēj. Rīga : DUE.

Mašnovskis, V. (2007) Latvijas luterāņu baznīcas: vēsture, arhitektūra, māksla un memoriālā kultūra, 4. sēj. Rīga : DUE.

Moltmann, J. (1972) Der gekreuzigte Gott: Das Kreuz Christi als Grund und Kritik christlicher Theologie. München : Kaiser Verlag.

Ozolinšs, A. (1937) Ēdoles baznīca. Jaunais Celšs, 5.

Rusmanis, S.; Vīks, I. (1993) Kurzeme. Rīga : Latvijas Enciklopēdija.

Spārītis, O. (1995) Vācbaltiešu kultūras vērtības Kurzemē. Kurzeme un kurzemnieki. Rīga : Latvijas Enciklopēdija, 90-92.

Švābe, A.; Būmanis, A.; Dišlers, K. (1929-1930) Latviešu konversācijas vārdnīca, 4. sēj. Rīga : A. Gulbis, 6147-8190.

Theissen, G.; Merz, A. (1996) Der historische Jesus. Göttingen : Vandenhoeck \& Ruprecht.

Vipers, B. (1937) Latvijas māksla baroka laikmetā. Rīga : Valters un Rapa. 